IZA DP No. 7097

Monetary Reference Points of Managers:

An Empirical Investigation of Status Quo

Preferences and Social Comparisons

Christian Grund

Johannes Martin

December 2012 


\title{
Monetary Reference Points of Managers: An Empirical Investigation of Status Quo Preferences and Social Comparisons
}

\author{
Christian Grund \\ RWTH Aachen University \\ and IZA
}

Johannes Martin

RWTH Aachen University

\section{Discussion Paper No. 7097 \\ December 2012}

\author{
IZA \\ P.O. Box 7240 \\ 53072 Bonn \\ Germany \\ Phone: +49-228-3894-0 \\ Fax: +49-228-3894-180 \\ E-mail: iza@iza.org
}

Any opinions expressed here are those of the author(s) and not those of IZA. Research published in this series may include views on policy, but the institute itself takes no institutional policy positions. The IZA research network is committed to the IZA Guiding Principles of Research Integrity.

The Institute for the Study of Labor (IZA) in Bonn is a local and virtual international research center and a place of communication between science, politics and business. IZA is an independent nonprofit organization supported by Deutsche Post Foundation. The center is associated with the University of Bonn and offers a stimulating research environment through its international network, workshops and conferences, data service, project support, research visits and doctoral program. IZA engages in (i) original and internationally competitive research in all fields of labor economics, (ii) development of policy concepts, and (iii) dissemination of research results and concepts to the interested public.

IZA Discussion Papers often represent preliminary work and are circulated to encourage discussion. Citation of such a paper should account for its provisional character. A revised version may be available directly from the author. 
IZA Discussion Paper No. 7097

December 2012

\section{ABSTRACT \\ Monetary Reference Points of Managers: An Empirical Investigation of Status Quo Preferences and Social Comparisons}

We assemble two reference point based concepts of utility in our empirical study: the own previous status quo and social comparisons. We explore the relative relevance of these concepts for total compensation as well as for different parts of the compensation package of managers. Making use of a unique panel data set of managers of the German chemical sector, we find that social comparisons of compensation indeed affect reported job satisfaction. Managers compare their total compensation (and fixed salary) with others in the chemical sector and report lower satisfaction scores when they earn less than similar managers. We find hardly any evidence for the relevance of status quo preferences.

JEL Classification: M5, J28, J31

Keywords: compensation, job satisfaction, reference points, social comparisons, status quo preferences

Corresponding author:

Christian Grund

RWTH Aachen University

School of Business and Economics

Templergraben 64

52056 Aachen

Germany

E-mail: christian.grund@rwth-aachen.de 


\section{Introduction}

In neoclassical economic theory, it is assumed that individuals solely care for their own monetary outcomes. Outcomes are usually represented by wages when analysing employees. In contrast, behavioral personnel economists argue that individuals also consider certain reference points when evaluating their income. Employee's utility does hence not only depend on absolute income level alone, but also on the relative value. Two possible reference points which are widely discussed in the literature are the own hitherto status quo (i.e. the most recent income level) and the income of peers. If the two types of reference points matter, individuals acting in a role as an employee may then take their own wage of the previous period or the wage of other employees into consideration in order to evaluate the utility of their own current income.

Previous studies on this topic analyze only one possible reference point (either the previous status quo or social comparisons) and only one measure of monetary outcome (fixed salaries, bonus, total compensation), making it impossible to evaluate the relative relevance of the two concepts. The dataset we use in this study, however, allows for just that. Similar to other contributions, self-assessed job satisfaction is used as a proxy measure of the utility gained from work. We address the following questions in particular:

(1) To what extent is job satisfaction affected by deviations from the hitherto compensation (status quo) and by the difference between the own wage and the wages of co-workers (social comparison)?

(2) Are there differences between comparisons on the firm level and on the industry level regarding the relevance of social comparisons?

(3) Are there differences between wage components in that the effects of reference points violations with respect to bonuses are different compared to those with respect to fixed salaries?

For the investigation of these research questions, we make use of a unique panel dataset with rich information on income components, work situation, and socio-demographics of managers of the German chemical sector. Employees in management positions are of big interest in regard to the research questions as firms pay them rather high wages in order to set monetary incentives We have individual panel data so that the relevance of possible deviations of the hitherto status 
quo can be explored. Moreover, the data includes information about the firm and the hierarchical level of managers and, thus, allows us to define reference groups that managers are supposed to compare their income to. We hereby distinguish between the market level and the firm level: Ex ante it is not clear, whether employees compare themselves to colleagues in the same firm or also to employees in similar jobs in other firms. Evidence may differ across wage components, too. Therefore, we conduct a separate examination for total compensation as well as for fixed salaries and bonus payments.

The remainder of the chapter is structured as follows: In section 2 we describe relevant theoretical approaches and give an overview of the existing empirical literature. The data and the variables are explained in section 3 , followed by the methodology in section 4 . The empirical results are presented in section 5 and discussed in section 6 .

\section{Theoretical approaches and previous empirical findings}

Income comparisons has ever since played a minor role in the economic literature (see Drakopoulos (2011) for an overview of the history of earnings comparisons in economics). However, there are several theoretical approaches that deal with these income comparisons. They partly originate from other social sciences, but are nowadays also established in behavioural economics.

As already mentioned, the relative income should be of great importance in regard to the resulting level of utility. However, we should also assume that, consistent with a traditional economic view, the absolute wage has a positive impact on utility as well.

In general, utility $\mathrm{U}$ of person $i$ will be a function of the own wage $w_{i}$ and some reference wage $w^{r e f}$ :

$$
\begin{aligned}
& U_{i}=f\left(w_{i}, w^{r e f}\right) \\
& \text { with } \frac{\partial U_{i}}{\partial w_{i}}>0 \text { and } \frac{\partial U_{i}}{\partial w^{r e f}} \gtrless 0 .
\end{aligned}
$$

While the influence of the current income is supposed to be positive in all cases, the connection between utility and the reference income seems less straightforward. In the following, we will illustrate several theoretical arguments and describe previous empirical findings. 


\subsection{Status quo preferences}

First theoretical foundations of the own hitherto status quo as reference point trace back to Markowitz (1952). He focused on investment strategies under risk and argued that the strategies are dependent on present wealth as well as previous individual gains and losses: Previous losses lead to a more conservative behaviour, whereas previous gains foster riskier investments. The Prospect Theory (Kahneman \& Tversky, 1979; Tversky \& Kahneman, 1991) enhanced this approach: Individuals evaluate a specific amount of money or other goods not only with respect to their absolute values, but also relative to a certain reference point. In this context, it is assumed that negative deviations from this reference point lead to a higher increment of disutility than positive deviations in the same magnitude lead to an increment of utility. This phenomenon is called loss aversion. With respect to status quo preferences, we should observe a negative effect on job satisfaction for employees faced with a wage decrease that is more pronounced than the positive effect of a wage increase.

A number of experimental studies reveal evidence that decisions of individuals depend on their endowment (e.g. Knetsch (1989), Kahneman, Knetsch \& Thaler (1990), and Franciosi, Kujal, Michelitsch, Smith \& Deng (1996)) Moreover, Hardie, Johnson \& Fader (1993) test the relevance of the Prospect Theory with respect to consumer decisions. In addition, several studies examine whether the labor supply of individuals depend on expectations about their income that are built on experiences in the past (see for instance Camerer, Babcock, Loewenstein \& Thaler (1997), Farber (2005), Farber (2008), or Crawford \& Meng (2011).Two contributions are particularly relevant in the context of our study. Clark (1999) analyzes employee data of two waves of the British Household Panel Survey (BHPS). In his cross-sectional investigation, he finds a strong positive correlation between the change in hourly pay and job satisfaction. Grund \& Sliwka (2007) confirm this finding with panel data of 19 waves of the German SocioEconomic Panel (GSOEP). The results are relevant for highly skilled white-collar workers in particular.

On the macroeconomic level, the Easterlin paradox states that economic growth with respect to the GDP does not improve compulsorily the average degree of happiness of a population (Easterlin, 1974). He explains it by increased aspiration levels that go along with income raises 
and undermine the positive effect of more income itself. ${ }^{1}$ Although his argumentation is on entire economies, one can also apply it to individuals and conclude that positive wage increases will not automatically entail positive effects on satisfaction because of rising aspiration levels. Hence, it is ex ante not clear whether income increases (= positive deviations from the hitherto status quo) lead to higher job satisfaction.

\subsection{Social comparisons}

In the context of social comparisons, Duesenberry (1949) as one of the first scholars described the importance of the social network of individuals for their decisions on consumption. He argued that individuals experience a feeling of relative deprivation when their neighbours own better cars or their friends live in bigger apartments. As a result, they also increase their expenditures to "keep up with the Joneses". The Social Comparison Theory of Festinger (1954) and the Equity Theory of Adams (1963) are more focused on labor market situations. It is thereby argued that individuals compare themselves to similar persons (neighbours or colleagues, for instance). More precisely, Equity Theory states that employees compare their own relation of their perceived inputs and their perceived outputs to that of their peers. Inputs can be the (perceived) efforts expended on their jobs or their skills and knowledge. Outputs are the rewards employees receive for their inputs. Rewards can take on all forms of monetary compensation, but can also be of non-monetary nature such as appreciation by a supervisor, for instance. A perceived inequity between the own input-output relation and that of their peers should affect utility and behaviour of employees: They might modify their own inputs (work more or less, for example), try to modify the inputs of their colleagues (e.g. sabotage them), try to modify their outcomes (ask for a wage increase, for instance), or finally quit their job. The fair wage-effort hypothesis proposed by Akerlof (1984) and Akerlof \& Yellen (1990) is based on Equity Theory: When the received wage falls below a certain wage which is considered as fair, employees withdraw their effort. The level of the fair wage is hereby the result of the comparison of own inputs and outcomes to those of the peers.

1 The Easterlin paradox, however, has faced its fair share of criticism, see for example Stevenson \& Wolfers (2008) for a comprehensive analysis. In contrast, in a recent contribution on the China case Easterlin, Morgan, Switek \& Wang (2012) present evidence that the average happiness level in China did not rise from 1990 until 2010 - even though the consumption per capita quadrupled during this time span. They explain their findings with the growing income inequality and the increased rate of unemployment which counteracts the positive effects of higher incomes for some parts of the Chinese population. 
In general, these approaches assume that individuals are averse to inequality. Based on experimental evidence, Fehr \& Schmidt (1999) as well as Bolton \& Ockenfels (2000) offer specific utility functions, which take this inequality aversion into account and predict a negative effect on utility. They distinguish between advantageous (i.e. $\mathrm{w}_{\mathrm{i}}>\mathrm{w}^{\mathrm{ref}}$ ) and disadvantageous (i.e. $\mathrm{w}_{\mathrm{i}}<\mathrm{w}^{\text {ref }}$ ) inequality. However, it seems reasonable to assume that the utility-diminishing effect of negative inequality is stronger than that of positive inequality. This idea is then quite similar to the idea of loss aversion as individuals fear to feel some kind of a "social loss".

However, Hirschman \& Rothschild (1973) present an argument in favor of a positive effect caused by a reference wage which is higher than the own income. They describe an information effect ${ }^{2}$, i.e. higher wages of others, serving as reference points. They could be interpreted as a signal for the future wage of the person in question. This effect, though, requires a realistic option that employees can at some point earn as much as their colleagues.

Besides these considerations with respect to disadvantageous situations, there are also theoretical considerations regarding the consequences of advantageous conditions. Frank (1985) argues that individuals have certain status preferences as they gain a benefit from obtaining a higher status than people in their peer group. Thereby, a higher status can be expressed by a better job or a higher wage. On the other hand, employees receiving a higher income than their peers might also feel regret or compassion towards the others so that their own utility is diminished.

Table 1 gives an overview of the possible effects of social comparisons on utility. From a theoretical perspective, however, it is ex ante unclear whether the positive or the negative effect will occur. It is also conceivable that both effects arise at the same time, possibly cancelling each other out.

---> Table 1 about here $<---$

There are several studies which investigate the empirical relevance of social comparisons, e.g. the comparisons to peers. In this context, Clark \& Senik (2010) found evidence that colleagues

2 Hirschman \& Rothschild call it a tunnel effect: "Suppose that I drive through a two-lane tunnel, both lanes going in the same direction, and run into a serious traffic jam (...) After a while the cars in the right lane begin to move. Naturally, my spirits lift considerably, for I know that the jam has been broken and that my lane's turn to move will surely come any moment now. Even though I still sit still, I feel much better off than before because of the expectation that I shall soon be on the move.” (Hirschman \& Rothschild, 1973, p. 545) 
are the most important group of reference persons. However, other studies stick to comparisons in different directions. The research approach thereby varies across studies. The seminal paper of Clark \& Oswald (1996) makes use of the 1991 wave of the BHPS. In order to calculate the reference wage, they estimate a Mincer-type wage regression with several wage determinants and predict the expected wage for all individuals. In this case, the reference point indicates the average wage an employee with given individual and firm characteristics can expect on the labor market. In their cross-sectional analysis, they find a significantly negative correlation between job satisfaction and this reference point, controlled for the own wage.

Ferrer-i-Carbonell (2005) defines the reference point as the average income of individuals living in the same region with the same education and the same age. She uses panel data of the GSOEP from 1992 to 1997 showing that the more individuals earn in comparison to their reference group, the more satisfied they are. This effect is asymmetric, which means that individuals with an income below the reference point are more dissatisfied than individuals with an income above the reference point (in the same amount) are satisfied. A similar result show the analyses of Luttmer (2005). He uses data of the US-American National Survey of Families and Households (NSFH) from 1987-1988 and 1992-1994 whereas reference groups are defined by people with the same occupation working in the same industry and living in the same region. He finds that happiness is negatively influenced by the average reference income. The effect of an increase in the earnings of neighbours has the similar size as a similarly sized decrease in own income.

Using GOSEP data from 2000 to 2004, Boes, Staub \& Winkelmann (2010) analyze whether the own income rank and the income rank of one's parents within a group influences income satisfaction. The reference group is determined by region and age. They find a positive and significant effect of both the own rank and the rank of one's parents. FitzRoy, Nolan \& Steinhardt (2011) compare the relevance of social comparisons in Germany and in Great Britain using panel data of the GSOEP and the BHPS. They define the reference group as individuals with same age, education, gender and living in the same region. Interestingly, they find an agedependent impact of the reference income for Germany: Whereas life satisfaction is negatively correlated with the average income of the reference group for those over 45 years of age, this correlation is positive for those under 45 years. They interpret this finding as a confirmation of Hirschman's tunnel effect in that individuals interpret higher wages of peers as possible signals for their own future wages. For Great Britain, the satisfaction effect of the reference income is negative for all age groups. 
Some studies analyze social comparisons on the level of firms. Brown, Gardner, Oswald \& Qian (2008) use cross-sectional data of the British Workplace Employee Relations Survey of 1998 and focus on employees. They operationalize monetary reference points by computing the individual wage rank within the firm. They find a highly significant and positive correlation of the wage rank with different measures of satisfaction. Moreover, the effect of the relative income position seems to be stronger than the effect of the absolute pay itself. Clark, Kristensen \& Westergård-Nielsen (2009) match waves of the Danish ECHP with administrative data. The results show that earnings matter for job satisfaction, but so do average earnings within the establishment: The higher the mean pay in the firm, the more satisfied workers are. In this context, the authors argue that the definition of the reference group is very important for the direction of the effect. When the wages of others could be the one's own future earnings (as in the case of higher paid co-workers), the effect is rather positive - wages exert a signal. However, when comparison earnings are not within reach, they act as an indication of a higher social status of others and the effect should be negative. Card, Mas, Moretti \& Saez (2010) conduct a field experiment with about 6,000 employees at the University of California. Within this experiment, a treatment group of employees gets information about a new website where wages of University employees are listed. Employees in the control group are not informed. They find a clear result: The information of the treatment group exerts a negative effect on the satisfaction of individuals who are paid the median wage of their unit and occupation, i.e. workers with comparable tasks. There is no effect, however, for people who get paid above the median. One conclusion of the authors is that it could be better for employers to keep secrecy regarding the payments of their employees.

The contribution which is possibly the closest to ours with respect to the data is Ockenfels, Sliwka \& Werner (2010). They compare executives of one multinational firm in two plants in Germany and the US. As they have information about the achievement of individual targets of the managers, they define the reference point as a bonus percentage of 100 percent. The bonus payment depends on to what degree managers have fulfilled their targets. Thereby, a value of 100 percent means that the manager fully meets the expectations of the supervisor. Furthermore, the bonus budget of supervisors is restricted which implies that they have to cut the payment of one or more managers if they want to pay other managers a higher bonus. In consequence, bonus percentages under the reference point could be understood as negative reference point violations. In the German plant, job satisfaction of managers is significantly reduced if they fall below the reference point, but there is no effect on satisfaction of managers with bonus 
percentages over 100 percent. In the United States, there is no significant effect. The authors explain this finding with the communication policy of the firm. American managers get no information about their bonus percentages, whereas German managers are entirely informed. Hence, the results of this study also suggest that firms could be better off when keeping secrecy about earnings and avoid too much transparency.

In conclusion, the results imply that individuals perceive a lower utility in most cases when their wage is below a certain social reference wage. The effects of reference points, however, depend on the selection of the reference person or group. We have to state, however, that there is no discussion about the economic significance of income comparisons for individual's utility up to now.

\section{Data and variables}

In our empirical analysis, we can use a unique panel dataset of highly qualified professionals and executives of the German chemical industry. It has been generated from a corresponding annual salary survey which we conduct in collaboration with the German association of executive staff of the chemical industry (Verband angestellter Akademiker und leitender Angestellter der Chemischen Industrie e.V. (VAA)). The survey is performed in the first two months of each year among the members of the VAA. ${ }^{3}$ According to statements of VAA officials, the sample is representative for the respective executives and managers of the chemical sector. ${ }^{4}$ Individuals are asked about their current job next to some demographic characteristics and their previous occupational career. In particular, there is detailed information on all components of their compensation such as fixed salaries and bonus payments as well as other integral parts such as exercised stock options, inventors' gratuities or jubilee payments.

Four waves of this survey of the years 2009 to 2012 are used for the empirical analysis. Compensation data are collected in retrospect so that the data covers the period from 2008 to 2011. The VAA negotiates annual collective agreements with the employers concerning

3 The VAA has about 20,000 members. Within the survey, the response rate is approximately 30 percent and is rather stable over the four years.

4 This might not be true for managers who work in management areas as HRM or the legal department. The VAA is an organization that represents the interests of executives against their employers - similar to a union for ordinary employees. Therefore, their counterparts on the employer side such as managers in the human resources department are normally not members of the VAA. The majority of the VAA members is working in functional areas such as production, sales, or research and development. 
minimum wage levels and working conditions. This contract is only valid for managers with a university degree in natural sciences and engineering, who account for 88 percent of the sample. Therefore, the sample is restricted to fulltime employees in West German plants who have such a university degree in natural science or engineering. Since the role of specific wage components shall be addressed - fixed salary and bonus payments in particular - only employees with a bonus contract are considered. Due to these restrictions, the sample size encompasses 14,773 observations over the four year period. There is information of about 3,700 managers each year. We can follow individuals over time, so that the dataset has an unbalanced panel structure.

We investigate the relevance of compensation for the perceived utility from work. Therefore, we make use of the reported job satisfaction of managers as its proxy ${ }^{5}$. General job satisfaction is surveyed with the question "How satisfied are you with your job?" on an 11-digit scale from 0 (totally unhappy) to 10 (totally happy). The average reported job satisfaction is 6.84 with the median and mode at 8 (see Figure 1 and Table 2). The distribution does not differ very much to the whole group of employees in Germany (see Grund \& Sliwka (2007) for corresponding evidence originating from representative GSOEP data). Figure 2 shows differences in job satisfaction over time. Most managers report a rather constant satisfaction as about only one fourth has a change of more than one satisfaction point from one year to another. Hence, it is likely that the effects which we estimate in regressions will be rather small.

\section{---> Figures 1 and 2 about here $<---$ \\ ---> Table 2 about here $<---$}

There is comprehensive information on individuals' compensation. Bonus payments are prevalent for managers in the chemical sector. Some employees also report other additional monetary components of compensation such as exercised stock options or gratuities for inventions in addition to their fixed salary. The average annual total compensation of the managers in the sample amounts to about $121,000 €$. The main part (79 percent) of compensation is assigned to fixed salaries and 16 percent account for bonus payments (see Table 2). The observation period covers an economically successful year of the German chemical sector (2008) and the subsequent economic crisis in 2009 and 2010. In 2011, the

5 See already Freeman (1978) for the reasoning that job satisfaction is a highly relevant variable in regard to economic issues. 
industry recovered to a certain extent. The fraction of bonus payments on total compensation in the sample decreases only slightly from 17 percent in the year 2008 to 14 percent in 2010 and goes up to 18 percent in 2011.

As mentioned above, we explore the role of monetary reference points next to the own compensation of the current period. Therefore, we use reported compensation of the previous year as the measure for the hitherto status quo. In doing so, a considerable number of observations is lost due to missing data (in particular all observations of the first wave of the panel for which we obviously do not have information for the previous year). Additionally, we compute social comparison wages by estimating cross-sectional Mincer-type wage median regressions. The results are then used to calculate predicted wages for individuals. Within the regressions, we control for the level of hierarchy ${ }^{6}$, work experience, and firm size. A manager with certain characteristics earns on average the predicted wage. We compute these comparison wages at two levels of the analysis. First, it is referred to the market level whereas all observations of the sample are included. Second, we conduct wage regressions on the firm level arguing that colleagues may be the relevant reference group. In doing so, only firms with a considerable number of observations can be considered. Therefore, the analysis is restricted to ten large firms. We give more detailed information on these reference wages in section 4.

The regression analysis on job satisfaction includes several control variables. These variables cover socio-demographic characteristics such as sex, being in a relationship, having children, and experience as well as job- and firm-level factors, which embrace the distance from home to the workplace (in $\mathrm{km}$ ), tenure (in years), firm size (8 dummies), and level of the hierarchy (4 dummies). Table 2 also offers some descriptive statistics of the control variables. Information on the operationalization of these items can be found in Table A1 in the appendix.

6 In order to have a comparable proxy of hierarchical levels across all firms in the industry, the questionnaire asks participants for a self-assessed classification in one of four different categories. Thereby, category 1 stands for the top management level and category 4 represents the lowest level of executives within the own firm. 


\section{Methodology}

We argued above that the own current wage as well as certain reference wages may have an effect on job satisfaction. Hereby, we differentiate between the roles of total compensation, fixed salaries, and bonus payments. Our baseline estimation can be described in general by the following equation

$$
\text { Job satisfaction }_{\mathrm{t}}=\alpha+\beta \cdot \text { wage }_{t}+\gamma \cdot \text { wage }^{r e f}+\delta^{\prime} X+\varepsilon \text {. }
$$

where reported job satisfaction act as dependent variable, $X$ characterizes a vector of control variables, and $\varepsilon$ stands for the error term. The current wage in terms of total compensation, fixed salaries or bonus payments is represented by wage $e_{t}$ and the reference wage by wage $e^{\text {ref }}$. A simple transformation shows that the effect of deviations of the reference wage from the own current wage is directly captured with the approach in equation (2):

$$
\mathrm{JS}_{\mathrm{t}}=\alpha+(\beta+\gamma) \cdot \text { wage }_{t}-\gamma \cdot\left(\text { wage }_{t}-\text { wage }^{\text {ref }}\right)+\delta^{\prime} X+\varepsilon
$$

Hence, $\gamma$ indicates the relevance of reference wages for job satisfaction. The results of estimations of (2) and (3) are equivalent in terms of the estimated coefficients $\alpha, \beta, \gamma$, and $\delta$.

This approach is based on the assumption that the satisfaction effect of the reference wage is equal in size for all managers, no matter whether their own current wage is higher or lower. However, theoretical considerations showed that there are some hints that negative deviations have a higher effect on satisfaction. Figure 3 illustrates this consideration with two different curves with respect to status quo preferences. The dashed line represents the effect on job satisfaction in the absence of loss aversion which is the result of an estimation of equation (2). In contrast, the continuous curve with the kink in the point of origin stands for the situation under the assumption of loss aversion.

\section{---> Figure 3 about here $<---$}

To test this approach econometrically, we extend (3) to:

$$
\mathrm{JS}_{\mathrm{t}}=\alpha+\beta \cdot \text { wage }_{t}+\gamma \cdot\left(\text { wage }_{t}-\text { wageref }^{\mathrm{r}}\right)+\delta \cdot\left(\text { wage }_{t}-\text { wage }^{r e f}\right) \cdot \text { Below }+\eta^{\prime} X+\varepsilon .
$$


Below represents a dummy which adopts "1" if managers earn less than their reference wage. The evidence of a higher effect of negative deviations would be revealed by a positive and significant coefficient $\delta$, which would indicate the steeper slope of the curve below the origin in Figure 3 as one has to add $\gamma$ and $\delta$. Note that, due to the interaction term, the coefficients of this equation are not any longer identical to the coefficients of (2) and (3).

We argued above that we want to investigate two possible monetary reference points. To test the

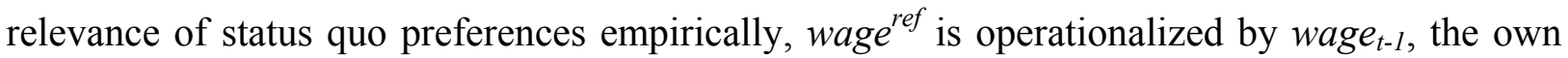
wage of one year before. Doing so, $\left(w a g e_{t}-w a g e_{t-1}\right)$ represents the absolute wage increase from last year to the current year. Moreover, we want to explore the relevance of social comparisons on two different levels. On the one hand, managers may compare themselves with the whole labor market of the chemical industry. Wages within the sector are transparent to a certain extent, as the VAA publishes an annual brochure including multiple descriptive analyses regarding the earnings of their members (based on the same dataset used in this contribution). Hence, managers should have some possibilities to compare their wages with those of others. Reference wages are thereby operationalized by the predicted wage managers would earn on average with their characteristics on the market. Mincer-type median ${ }^{7}$ wage regressions are estimated for total compensation, fixed salary and bonus payments. As wages within the chemical sector differ considerably between the four years, separate cross-sectional regressions for each year are conducted. Within the estimations, it is controlled for firm size, work experience, and hierarchical level, as these are the most important determinants of wages within the chemical industry. ${ }^{8}$ In consequence, the predicted wage reflects the wages executives would earn on average with their individual firm size, work experience, and hierarchical level in a given year.

Besides these social comparisons to other managers in the market, managers may also compare their wages with to salaries of their intra-firm colleagues. The operationalization of the corresponding reference wage is similar as wages are also predicted after running Mincer-type median wage regressions. However, only observations of a particular firm are included. Analogously, separate cross-sectional regressions for each of the four years are estimated. It is controlled for work experience and hierarchical level. The predicted wage in this case reflects

7 The use of quantile regressions is preferred over linear OLS models because the median is more robust as the mean is to outliers in the sample (especially in small samples like this). However, the results do not differ considerably from the use of usual linear OLS regression for computing the reference wages.

8 The adjusted $\mathrm{R}^{2}$ of equivalent OLS estimations instead of quantile regressions reaches over 60 percent. 
the income managers should earn on average given their work experience and hierarchical level in the firm. Therefore, the analysis focuses only on firms with sufficient observations in the single years so that only ten bigger firms are considered.

These approaches use absolute wage terms. We will also analyze relative wage increases by replacing the absolute income terms in the equations above by the log of wages. Thereby, we will apply linear estimation models in order to get effects which can be easily interpreted. ${ }^{9}$ To begin with, we make use of a simple OLS estimation to explore differences between individuals. However, as pointed out by Ferrer-i-Carbonell \& Frijters (2004), it is important to control for time-invariant heterogeneity in order to investigate potential effects on individual satisfaction. ${ }^{10}$ Thus, panel estimators will also be applied. The main focus will be on fixed-effects models as these allow for a correlation between the unobserved factors and the independent variables. However, as proposed by Wooldridge (2006, p. 491), we will also display the coefficients of similar random-effects models in order to get the entire picture. One potential problem with fixed-effects models, however, is their need of a sufficient intra-personal variation in both the dependent and the independent variables in order to get significant results. In the case of insufficient variation, one can explore the differences between the managers by using OLS models, but it is difficult to make inferences with respect to effects on satisfaction. It is likely that payments vary over time. In contrast, job satisfaction is rather stable (as shown above). It has to be seen whether we can nonetheless reveal significant effects. ${ }^{11}$

Next to the relevance of absolute and relative deviations of the own wage from a certain reference wage, we will investigate whether the individual wage rank within the reference group affects job satisfaction (see Brown, Gardner, Oswald \& Qian (2008) and Boes, Staub \& Winkelmann (2010) for similar approaches). The model is then described by

9 Another possibility would be ordered probit probability models. However linear models that estimate quantitative satisfaction effects of wage increases seem to be more appropriate in the context of this study. Furthermore, models with fixed effects cannot easily be estimated in the ordered probit case.

10 In addition, they show that it is of minor importance for the analysis of determinants of satisfaction whether an ordered response model or a linear model is applied. It is more important to control for fixed effects.

11 Low variation could be a problem regarding some control variables, too. For example, inter-firm job mobility in the chemical sector is rather low. Moreover, climbs on the intra-firm job ladder from level 3 to 2 or even 2 to 1 are rare. Hence, we should expect no considerable satisfaction effects of the hierarchical level due to the low number of individual switches. 


$$
\mathrm{JS}_{t}=\alpha+\beta \cdot \text { wage }_{\mathrm{t}}+\gamma \cdot \text { wage }_{\text {rank, } t}+\delta^{\prime} X+\varepsilon
$$

The rank is the individual wage percentile within a reference group. On the market level, these groups are defined by the same firm size, the same hierarchical level, and the same category of work experience. ${ }^{12}$ On the firm level, they are defined by the same hierarchical level and the same category of work experience. We make use of OLS, random-effects, and fixed-effects models for the estimations.

One potential problem when exploring the effect of wages on job satisfaction is endogeneity as a higher satisfaction score may be a determinant or a consequence of a higher wage. However, the chronology of the survey limits this problem. Participants are asked about their individual job satisfaction at the time of the interview (which is in January or February in most cases). Current wages, however, indicate the annual payments from the most recent year. Thus, wage payoffs precede the reporting of job satisfaction.

In the following chapter, we present our empirical results with respect to monetary reference points of managers.

\section{Empirical results}

The chapter is structured as follows: First, the relevance of status quo preferences is investigated. Then, we explore social comparisons both on the market level and on the firm level.

\subsection{Relevance of status quo preferences}

First, we investigate deviations from the own previous status quo (= wage increases/decreases). Table 3 presents the results for absolute wage differences, whereas models (1) to (3) show the OLS, RE, and FE estimations for total compensation and models (4) to (6) those for fixed

12 Due to the sample size, it is not possible to consider managers with exactly the same number of years of work experience as reference peers since the groups would become too small. Because of that, work experience is divided into eight categories: 1-5 years, 6-10 years, 11-15 years, 16-20 years, 21-25 years, 26-30 years, 31-35 years, and over 35 years. 
salaries and bonus payments as separate regressors. ${ }^{13}$ The models are based on roughly 7,000 observations since wage information on the previous year had to be available for an observation to be included. Because of that, we lose in particular all observations of the first wave. In the cross-sectional analysis, the coefficients of current payments (total compensation, fixed salaries, and bonus payments) are significant which indicates that the satisfaction of managers increases in their wages. However, this result does not hold when it is controlled for unobserved heterogeneity within the fixed-effects model. This shows that managers who receive a higher wage also report a higher level of job satisfaction, which is due to other differences that cannot be observed and are not a result of the income premium. When we turn to the past payments, a negative and significant coefficient would indicate status quo preferences (as described in chapter 4), but we do not see any significant results (except for fixed salaries in the OLS estimation), meaning that there is no evidence for a linear correlation or even causality between job satisfaction and absolute wage increases.

The coefficients of the random-effects models differ significantly from the fixed-effects model so that we can assume that the unobserved factors are correlated with the other independent variables. Hence, the fixed-effects models should be preferred. Having a look at the control variables, we see a negative influence of tenure. Surprisingly, a prolonged distance to work is associated with a higher satisfaction. ${ }^{14}$ All other controls do not exert an influence on satisfaction which is supposed to be at least partly due to small individual variation over time. The explanatory power of the models is rather low shown by small $\mathrm{R}^{2}$ values. This should not be a major problem for interpreting the coefficients as long as there are no important other (unobservable) factors which are correlated with the wage variables. If this is the case, the wage effects would be biased. However, there are no hints towards the potential existence of such factors.

13 These models embrace variables for both fixed salaries and bonus payments in each case. As both wage components are highly correlated, separate models for fixed salaries and for bonus payments would lead to biased results with respect to the coefficients of the wage variables.

14 One can assume that this is not the true causality. It could be that the increase in the distance to the workplace is a proxy for an individual employer change. If this is the case, the positive effect should rather be due to other improvements that came along with the change. The cross-sectional analyses support this hypothesis as managers with a longer distance to their workplace report significantly lower satisfaction scores. However, there is no direct information about employer changes in the data. One may apply an indirect approach by looking at managers with a tenure $\leq 1$ year. These are only 108 observations ( 0.7 percent). Therefore, it is abstained from a more detailed investigation at this point. 
The connection between job satisfaction and relative wage differences is shown in Table 4. Note that about 700 observations are lost due to zero bonus payments which cannot be transformed by the logarithm function. Most results are similar to those of Table 3. The effect of the bonus of the previous year is now significant with a surprisingly positive sign. The effect size is very small, though.

\section{---> Table 4 about here <---}

We argue in chapters 2.1 and 4.1 that loss aversion could be relevant in the context of status quo preferences as individuals perceive an extraordinarily high disutility of earning less than the year before. One may then expect a positive coefficient of the interaction between the wage difference and the Decrease dummy. The results for absolute differences are shown in Table 5. However, they do not indicate that this is really the case. Even with significant coefficients for fixed salaries and bonus payments in the OLS model of relative differences, the result does not hold when it is controlled for unobserved heterogeneity within the fixed-effects estimation.

\section{---> Table 5 about here <---}

Individual wage differences over time may result from job changes. Thus, aspects of a new job like a change of tasks and getting to know other colleagues should influence satisfaction. Restricting the sample on managers who did not change their functional area, hierarchical level or firm the results only little, though. Re-estimating model (6) of Table 3, we get a weakly significant negative coefficient for fixed salaries from the previous year. However, the results concerning the relevance of status quo preferences in Table 4 and 5 do not change.

To sum up, there is hardly any evidence for the relevance of status quo preferences of managers.

\subsection{Social comparisons}

After the investigation of the hitherto status quo as a possible reference point, we address the relevance of social comparisons in the following section. It starts with comparisons on the market level. 


\subsubsection{Market level}

As there are no restrictions on observations with sufficient wage data from both the current and the previous year anymore, we now explore the whole sample of about 14,800 observations. To start with the absolute difference between wage and reference wage (computed as described in chapter 4), Table 6 presents the results for total compensation as well as fixed salaries and bonuses. The relevance of social comparisons is indicated by the coefficient of the respective reference wages. First, comparing the results to those of the analyses of status quo preferences (see Table 3), we do not see any considerable differences with respect to the coefficients of the control variables. A similar picture also emerges for the coefficients of the current payments. Moreover, the reference wages with respect to total compensation and to fixed salaries exert a negative and significant influence on job satisfaction. In other words, the bigger the differential between the wage and the reference point on the market is, the higher is the reported satisfaction. This result remains robust in fixed-effects estimations so that it can be interpreted as an effect on job satisfaction. The marginal effects are thereby considerably higher than those of the own income which is in favor of a certain relevance of social comparisons. Besides, the effects for fixed payments are more pronounced than those for total compensation. It is also evident that the coefficients become smaller when it is additionally controlled for unobserved heterogeneity (what the fixed-effects estimations do). Overall, the results are quite similar focusing on relative differences in Table 7 .

However, effect sizes are rather small. A total compensation which is $10,000 €$ below the reference wage diminishes the satisfaction score ceteris paribus by only $10 \times 0.0110 \approx 0.1$ points. Similarly, earning 10 percent less than the reference wage leads to a satisfaction decrease of about $10 \mathrm{x} 0.01343 \approx 0.1$ points. Related to the overall variation of job satisfaction (see Table 2 ), this represents only 5 percent of one standard deviation. However, the impact with respect to fixed salaries is considerably larger. Here, a 10,000 $€$ deviation leads to an effect on job satisfaction of $10 \times 0.0263 \approx 0.3$ points.

\section{---> Tables 6 and 7 about here $<---$}

There are some arguments that managers who earn less than their counterparts suffer in particular from this situation (see chapter 2.2). We test this possible social loss aversion, with the results for absolute differences presented in Table 8 . The relevance of social loss aversion is indicated by the coefficient of the interaction term between the respective wage differences and the Below dummy, whereas social loss aversion would be shown by a positive coefficient. In the 
cross-sectional model with respect to total compensation, we see a positive and significant coefficient of the interaction term of the wage difference and the dummy variable for managers earning less than the reference income. Indeed, the interaction term for bonus payments is significant. However, the overall effect for managers receiving a bonus which is lower than their reference bonus is not significant as one has to add the main effect for the difference between the own bonus and the reference bonus (= the effect/slope for managers over the reference point) which has a negative sign and a similar size. ${ }^{15}$ The significances, though, disappear when controlling for unobserved heterogeneity in the fixed-effects models. Regarding fixed salaries, there is no evidence for social loss aversion. Running corresponding regressions with logarithmized wages does not lead to significant results for any wage component with respect to social loss aversion.

\section{---> Table 8 about here $<---$}

Finally, we investigate a potential correlation between individual's rank within the wage distribution on the whole labor market and job satisfaction. The results in Table 9 show a positive impact of a higher rank for all three income types. For fixed salaries and bonuses, however, the significance disappears in the fixed-effects model. The effects are also rather small as, for instance, the satisfaction differential between the $10^{\text {th }}$ percentile and the $90^{\text {th }}$ percentile for total compensation is only $80 \mathrm{x} 0.0026 \approx 0.2$ satisfaction points. ${ }^{16}$

\section{---> Table 9 about here <---}

\subsubsection{Firm level}

In the previous section, we investigated whether managers compare their own wage to wages that are paid on the whole labor market. Beside this inter-firm comparison, it is not unlikely that individuals take the wages of co-workers into account as well. The relevance of these kinds of comparisons will be explored in this subsection.

The analyses are thereby restricted to managers of ten large firms within the chemical industry as a sufficient number of observations per year and per firm is necessary in order to compute

\footnotetext{
15 This can be statistically tested by reversing the dummy variable that is interacted with the absolute bonus difference. This reveals a non-significant effect.

16 We also tested whether the correlation between job satisfaction and the wage rank follows a non-linear path by adding a squared term of the wage percentile to the regression. However, its coefficient is not significant.
} 
reference wages. The results for absolute differences with and without loss aversion are presented in Tables 10 and 11. However, most of the coefficients are not significant, especially in the fixed-effects models. Hence, it is not possible to speak of a relevance of intra-firm social comparisons within these ten big firms.

\section{---> Tables 10 and 11 about here $<---$}

\subsection{Investigation of subgroups}

In the following, we explore whether the impact of relative income on job satisfaction is different when looking at several subgroups of the sample. As there are no hints for the relevance of status quo preferences, analyses are focused on social comparisons.

First, one might think of gender differences with respect to the sensitivity for reference incomes. Whereas men care especially for their relative position, there is no evidence at all that women compare their own income to those of others: The coefficient is much smaller and far from being significant (see Table 12). One explanation could be that the reference income used here might be not appropriate for women. As we do not control for gender within the Mincer regressions which estimate the reference income and the sample consists of male managers in the majority, these predicted earnings are virtually those of men. ${ }^{17}$ But when they know that there are only few female managers in the chemical sector, especially on higher hierarchical levels, women may anticipate their worse career opportunities in comparison to men. Then, male earnings would not be adequate reference incomes in order to evaluate the own job situation. A better reference point might be the average income of women with equivalent characteristics. Therefore, we compute new reference incomes by estimating Mincer regressions with an additional gender dummy. However, when using these earnings as reference wages in models (2) and (4) of Table 12, the coefficients remain small and far from being significant. This result allows for the conclusion that women actually do not care for incomes of others. This is in line with the results of early-stage work by Mayraz, Wagner \& Schupp (2009) and Mumford \& Smith (2012).

---> Table 12 about here $<---$

17 The reason for not controlling for gender in the estimations is that firms do not distinguish between women and men in their remuneration systems. 
We also explore differences in firm size categories, see Table 13 for the results. These show a remarkable pattern: Managers in smaller firms with up to 1,000 employees seem to compare themselves more to the market than executives in bigger plants do. The coefficients of reference wages are larger than in firms with more employees, even though they are not significant in the case of fixed salaries and bonuses. This result holds true when relative differences are explored.

\section{---> Table 13 about here <---}

We also tested whether there are any differences between managers at the beginning of their career and older executives. One might think that younger managers are more focused on their career opportunities rather than on their relative income. However, the results did not reveal any considerable differences. Another idea might be that managers with a different education (e.g. in business or economics) are more or less influenced in their job satisfaction by the income of their peers. Up to now, only persons with a university degree in natural sciences and engineering were in the sample as these managers represent almost 90 percent of the data. When looking at managers with an education in business or economics and defining their reference group as managers with the same education, the results with respect to social comparisons are far from being significant. The main reason for that should be the small sample size of roughly 800 observations.

\section{Summary and discussion}

In the traditional view of economics, individuals are egoistic and exclusively care about their own income. However, several approaches in the field of behavioral economics suggest that individuals also take certain monetary reference points into account when evaluating their income situation. Using a unique dataset of executives in the German chemical sector, we explored the relevance of two possible reference points in practice: the wage from the previous one year (status quo preferences) and the wages of comparable managers (social comparisons). There is hardly any evidence for the relevance of status quo preferences amongst the executives in the German chemical sector. They do not seem to care much about wage increases, but rather about the current remuneration they get. One explanation could be that managers already expected these increases or decreases. As mentioned above, we observe considerable lower bonus payments in 2009 and 2010 which is a clear impact of the financial and economic crisis. Managers obviously knew that their firms struggled with the difficult situation. So it is very likely that they also anticipate lower bonus payments in these years and are not bothered by 
decreases compared to the previous year. With respect to fixed salaries, they know from experience that their employer raises fixed salaries every year by a certain percentage. ${ }^{18}$ In consequence, the size of wage differences between two subsequent years is not surprising for managers and, thus, has no impact on their job satisfaction.

In contrast, the results show that social comparison processes are important for the utility of work. Hence, next to the absolute wage payment which exerts a positive influence on job satisfaction, managers also take the income of others in account when evaluating their own situation. This effect, though, is only significant with respect to comparisons on the market level, but not when comparison processes on the firm level are investigated. The effect on the market level remains robust in analyses of absolute and relative differences between own salaries and reference wages as well as in analyses of the individual wage rank within a reference group.

Our analysis of intra-firm comparison processes within ten bigger firms did not show any significant results. Several reasons come to mind: First, this could simply be due to a small sample size. Second, the variation with respect to wages on the firm level is considerably smaller than on the market level: Whereas the average deviation from the computed reference total compensation is +2.6 percent $^{19}$ on the market level, it is only +0.9 percent on the firm level. But when managers earn almost the same as the reference income, it is difficult to find considerable effects of deviations on satisfaction. Third, it may be the case that the wages of colleagues are simply not known to the managers. In contrast, market wages may be more transparent, because employees receive general results of the yearly VAA compensation survey. Fourth, the reference groups within the firms may not be specific enough. In most cases, firms have more than four levels within their remuneration system. Hence, the use of only four hierarchical levels which are harmonized across the whole industry may lead to reference groups which, in terms of their definition, are not narrow enough to capture the actual situation on the firm level. If this is the case and, for example, the fourth VAA level combines two wage stages in the system of a certain firm, the computed reference wage is then located somewhere between these two levels. It is obvious that this wage would not be a sensible proxy for the actual intrafirm reference point of managers. Unfortunately, information concerning wage levels within

18 Only 11 percent of the managers in the sample have a decrease in their fixed salaries. For only 4 percent of managers, the decrease is more than 5 percent.

19 Computed as the average difference between the logarithmized own total compensation and the logarithmized reference total compensation. 
firms is incomplete and not surveyed systematically. Moreover, the formal structure of remuneration systems is only known in some cases. It therefore remains a task for future research to investigate intra-firm comparison processes with more adequate data.

The investigation of different subgroups revealed considerable gender differences as there are no significant effects of reference wages on job satisfaction of female managers at all. We explore whether this might be due to an operationalization of reference incomes that is not adequate for female managers, but there were no hints for this reason. Another explanation might be gender differences with respect to competitive behavior. There are some indications in the literature that women are less willing than men to compete with others (Niederle \& Vesterlund, 2007; Price, 2008). Income comparisons itself, however, are some kind of competition which may explain their missing relevance in the case of female managers.

The relevance of social comparisons is higher for managers who work for smaller firms. As executives on higher hierarchical levels, those managers have fewer adequate reference persons within the own firm. Maybe because of that, they rather look at the outside labor market in order to evaluate their market value or to investigate their outside options. In contrast, managers in larger firms should compare themselves to a larger extent with co-workers since it is more likely that there are comparable people in the same establishment. The results for social comparisons within firms, however, cannot confirm this as discussed above.

One limitation of our data is that we do not have any information about individual performance of managers. Under the assumption that wages depend on individual performance (which is often evaluated by subjective performance appraisals) to some extent, effects of positive or negative differences to the reference wage may also reflect positive or negative feedback by the supervisor. However, our fixed-effects approach investigates individual differences over time. We suppose performance evaluations to be rather stable over time as performance is influenced by individual productivity, personality and other factors that should not change considerably from one year to another. Then, the feedback by the supervisor is a rather time-constant factor and, thus, not relevant for the satisfaction effect measured in a fixed-effects estimations. This leads us to the conclusion that we actually revealed monetary reference points.

At last, we have to address the economic significance of the statistically significant results. It has been shown that the impact of deviations from the reference point is small. A difference of $10,000 €$ leads to effects on job satisfaction of only 0.1 points (total compensation) and 0.3 points (fixed salaries). Compared to other working conditions, this impact is low. For 
instance, a promotion from level 4 to level 3 leads to an increase in satisfaction of about 0.4 points which is independent from the additional positive effect of a wage increase that usually goes along with a promotion. The effect of an employer change is even more pronounced: At least for this small sample of 108 observations, the impact is almost 2 points of job satisfaction. Even though the causality and possible endogeneity problems (Does the employer change lead to a higher job satisfaction? Or were those managers already dissatisfied before moving to another firm?) are up for debate, the size of the effect is considerably higher than those of social comparisons.

One explanation for this discrepancy in the size of effects could be that executives and managers are on a rather high income level. Usually, they do not need to worry about their own personal financial and economic situation. Therefore, other aspects of the job are of higher importance for their well-being at work. This would explain the low effect for both the absolute income and also the relative income (with respect to the hitherto status quo and social comparisons). In addition, the results may be interpreted in the way that managers simply do not know or are even not interested in how much others in the market or in their firm earn as they are rather fine with their remuneration. This could explain the low impact of both the own and the reference wages on job satisfaction as a measure of the overall utility gained from work.

It seems that the result of small effects is not unique for this rather selective sample of executives in the German chemical sector. Clark, Kristensen \& Westergård-Nielsen (2009), who explore representative and administrative data from Denmark, also find rather small impacts of average earnings paid in the firm of individuals on their satisfaction level. In their view, this "is typical in subjective data, where the dependent variable is often tightly distributed" (Clark, Kristensen \& Westergård-Nielsen, 2009, p. 439). An indication that the assessment of other, more income-related measures of utility would lead to higher effects provides the contribution of Boes, Staub \& Winkelmann (2010). They make use of a GSOEP question that asks about individual's satisfaction with pay and find considerable higher effects of income. However, when discussing the overall economic importance of reference wages, it seems to be more appropriate to make use of a measure of overall job satisfaction. Future research should focus more on this question of economic significance. Up to now, it is not possible to draw a clear conclusion as the majority of other contributions apply ordered probit models which inhibits comparisons of effect sizes. It would be interesting to analyze the relevance of comparisons to both the own previous status quo and a certain reference group in a joint analysis with other data. It would then be possible to compare the results of this chapter on the group of managers to 
results on other employee groups. Moreover, one could extend the analysis to the satisfaction with pay.

Even though we also explored intra-firm processes, the focus in this chapter was on employee's perspective. On the base of job satisfaction, it is difficult to make inferences for wage policies of firms, since the connection between job satisfaction and consequences for the behavior of employees such as lowering productivity or quitting the firm seems not straightforward. On the one hand, employees who earn less than others might understand this as a signal by the supervisor or by the firm that they underperformed previously, leading to an increase of productivity afterwards not to lose career opportunities within their firm. On the other hand, this situation could be seen as a relative deprivation, leading to resigning employees or, in the case of comparisons on the labor market level, to managers that explore their outside options. Some studies analyze other economic effects of earning less than others. However, it is difficult to assign their results to managers as these studies are either laboratory experiments or analyze other groups of employees as described in the literature overview above. One exception is the work by Ockenfels, Sliwka \& Werner (2010). The authors find a negative effect of a higher fraction of managers with a bonus percentage below 100 percent within a department on the performance rating of the supervisor in the subsequent year. As supervisor's performance is supposed to be influenced by the performance of the direct subordinates, they assume that the negative effect is due to a decreased performance of those managers with a bonus percentage below 100 percent in the previous year. However, this is a rather indirect approach. With additional waves of our survey in the future that builds up the dataset used in this chapter, it may be possible to investigate other effects such as quit behavior in more detail. 


\section{References}

Adams, J. Stacy (1963): Toward an Understanding of Inequity. In: Journal of Abnormal and Social Psychology 67. 422-436.

Akerlof, George A. (1984): Gift Exchange and Efficiency-Wage Theory: Four Views. In: American Economic Review 74. 79-83.

Akerlof, George A.; Yellen, Janet L. (1990): The Fair Wage-Effort Hypothesis and Unemployment. In: Quarterly Journal of Economics 105. 255-283.

Boes, Stefan; Staub, Kevin; Winkelmann, Rainer (2010): Relative Status and Satisfaction. In: Economics Letters 109. 168-170.

Bolton, Gary E.; Ockenfels, Axel (2000): ERC: A Theory of Equity, Reciprocity, and Competition. In: American Economic Review 90. 166-193.

Brown, Gordon D. A.; Gardner, Jonathan; Oswald, Andrew J.; Qian, Jing (2008): Does Wage Rank Affect Employees’ Well-Being? In: Industrial Relations 47. 355-389.

Camerer, Colin; Babcock, Linda; Loewenstein, George; Thaler, Richard (1997): Labor Supply of New York City Cab Drivers: One Day at a Time. In: Quarterly Journal of Economics 112. 407.

Card, David; Mas, Alexandre; Moretti, Enrico; Saez, Emmanuel (2010): Inequality at Work: The Effect of Peer Salaries on Job Satisfaction. NBER Working Paper No. 16396.

Clark, Andrew E. (1999): Are Wages Habit-Forming? Evidence from Micro Data. In: Journal of Economic Behavior \& Organization 39. 179.

Clark, Andrew E.; Kristensen, Nicolai; Westergård-Nielsen, Niels (2009): Job Satisfaction and Co-worker Wages: Status or Signal? In: Economic Journal 119. 430-447.

Clark, Andrew E.; Oswald, Andrew J. (1996): Satisfaction and Comparison Income. In: Journal of Public Economics 61. 359.

Clark, Andrew E.; Senik, Claudia (2010): Who Compares to Whom? The Anatomy of Income Comparisons in Europe. In: Economic Journal 120. 573-594. 
Crawford, Vincent P.; Meng, Juanjuan (2011): New York City Cab Drivers' Labor Supply Revisited: Reference-Dependent Preferences with Rational-Expectations Targets for Hours and Income. In: American Economic Review 101. 1912-1932.

Drakopoulos, Stavros A. (2011): The Neglect of Comparison Income: A Historical Perspective. In: The European Journal of the History in Economic Thought 18. 441-464.

Duesenberry, James B. (1949): Income, Saving and the Theory of Consumer Behavior. Cambridge.

Easterlin, Richard A. (1974): Does Economic Growth Improve the Human Lot? In: David, P.A., Reder, M.W. (Eds.): Nations and Households in Economic Growth: Essays in Honor of Moses Abramovitz. New York.

Easterlin, Richard A.; Morgan, Robson; Switek, Malgorzata; Wang, Fei (2012): China's Life Satisfaction, 1990-2010. In: Proceedings of the National Academy of Sciences.

Farber, Henry S. (2005): Is Tomorrow Another Day? The Labor Supply of New York City Cab Drivers. In: Journal of Political Economy 113. 46-82.

Farber, Henry S. (2008): Reference-Dependent Preferences and Labor Supply: The Case of New York City Taxi Drivers. In: The American Economic Review 98. 1069-1082.

Fehr, Ernst; Schmidt, Klaus M. (1999): A Theory of Fairness, Competition, and Cooperation. In: Quarterly Journal of Economics 114. 817-868.

Ferrer-i-Carbonell, Ada (2005): Income and Well-Being: An Empirical Analysis of the Comparison Income Effect. In: Journal of Public Economics 89. 997-1019.

Ferrer-i-Carbonell, Ada; Frijters, Paul (2004): How Important is Methodology for the Estimates of the Determinants of Happiness? In: Economic Journal 114. 641-659.

Festinger, Leon (1954): A Theory of Social Comparison Processes. Indianapolis.

FitzRoy, Felix R.; Nolan, Michael; Steinhardt, Max F. (2011): Age, Life-Satisfaction, and Relative Income: Insights from the UK and Germany. IZA Discussion Paper No. 6045. 
Franciosi, Robert; Kujal, Praveen; Michelitsch, Roland; Smith, Vernon; Deng, Gang (1996): Experimental Tests of the Endowment Effect. In: Journal of Economic Behavior \& Organization 30. 213-226.

Frank, Robert H. (1985): Choosing the Right Pond: Human Behavior and the Quest for Status. New York.

Grund, Christian; Sliwka, Dirk (2007): Reference-Dependent Preferences and the Impact of Wage Increases on Job Satisfaction: Theory and Evidence. In: Journal of Institutional and Theoretical Economics 163. 313-335.

Hardie, Bruce G. S.; Johnson, Eric. J.; Fader, Peter S. (1993): Modeling Loss Aversion and Refernce Dependence Effects on Brand Choice. In: Marketing Science 12. 378-394.

Hirschman, Albert O.; Rothschild, Michael (1973): The Changing Tolerance for Income Inequality in the Course of Economic Development. In: Quarterly Journal of Economics 87. 544-566.

Kahneman, Daniel; Knetsch, Jack L.; Thaler, Richard (1990): Experimental Tests of the Endowment Effect and the Theorem. In: Journal of Political Economy 98. 1325-1348.

Kahneman, Daniel; Tversky, Amos (1979): Prospect Theory: An Analysis of Descision Under Risk. In: Econometrica 47. 263-291.

Knetsch, Jack L. (1989): The Endowment Effect and Evidence of Nonreversible Indifference Curves. In: American Economic Review 79. 1277-1284.

Luttmer, Erzo F. P. (2005): Neighbors as Negatives: Relative Earnings and Well-Being. In: Quarterly Journal of Economics 120. 963-1002.

Markowitz, Harry (1952): The Utility of Wealth. In: Journal of Political Economy 60. 151158.

Mayraz, Guy; Wagner, Gert G.; Schupp, Jürgen (2009): Life Satisfaction and Relative Income: Perceptions and Evidence. IZA Discussion Paper No. 4390.

Mumford, Karen; Smith, Peter N. (2012): Peer Salaries and Employee Satisfaction in the Workplace. IZA Discussion Paper No. 6673. 
Niederle, Muriel; Vesterlund, Lise (2007): Do Women Shy Away from Competition? Do Men Compete Too Much? In: Quarterly Journal of Economics 122. 1067-1101.

Ockenfels, Axel; Sliwka, Dirk; Werner, Peter (2010): Bonus Payments and Reference Point Violations. IZA Discussion Paper No. 4795.

Price, Joseph (2008): Gender Differences in the Response to Competition. In: Industrial \& Labor Relations Review 61. 320-333.

Stevenson, Betsey; Wolfers, Justin (2008): Economic Growth and Subjective Well-Being: Reassessing the Easterlin Paradox. In: Brookings Papers on Economic Activity. 1-102.

Tversky, Amos; Kahneman, Daniel (1991): Loss Aversion in Riskless Choice: A ReferenceDependent Model. In: Quarterly Journal of Economics 106. 1039-1061.

Wooldridge, Jeffrey M. (2006): Introductory Econometrics. Mason, Ohio. 


\section{Tables and Figures}

Table 1: Possible utility effects of social comparisons

\begin{tabular}{|l|c|c|}
\hline & \multicolumn{2}{|c|}{ Effect on utility } \\
\hline Relative wage & Positive & Negative \\
\hline $\mathrm{w}_{\mathrm{i}}>\mathrm{w}^{\text {ref }}$ & Status effect & Regret/Compassion \\
\hline $\mathrm{w}_{\mathrm{i}}<\mathrm{w}^{\text {ref }}$ & $\begin{array}{c}\text { Relative deprivation } \\
=\text { social loss }\end{array}$ & Information effect \\
\hline
\end{tabular}

Figure 1: Distribution of job satisfaction

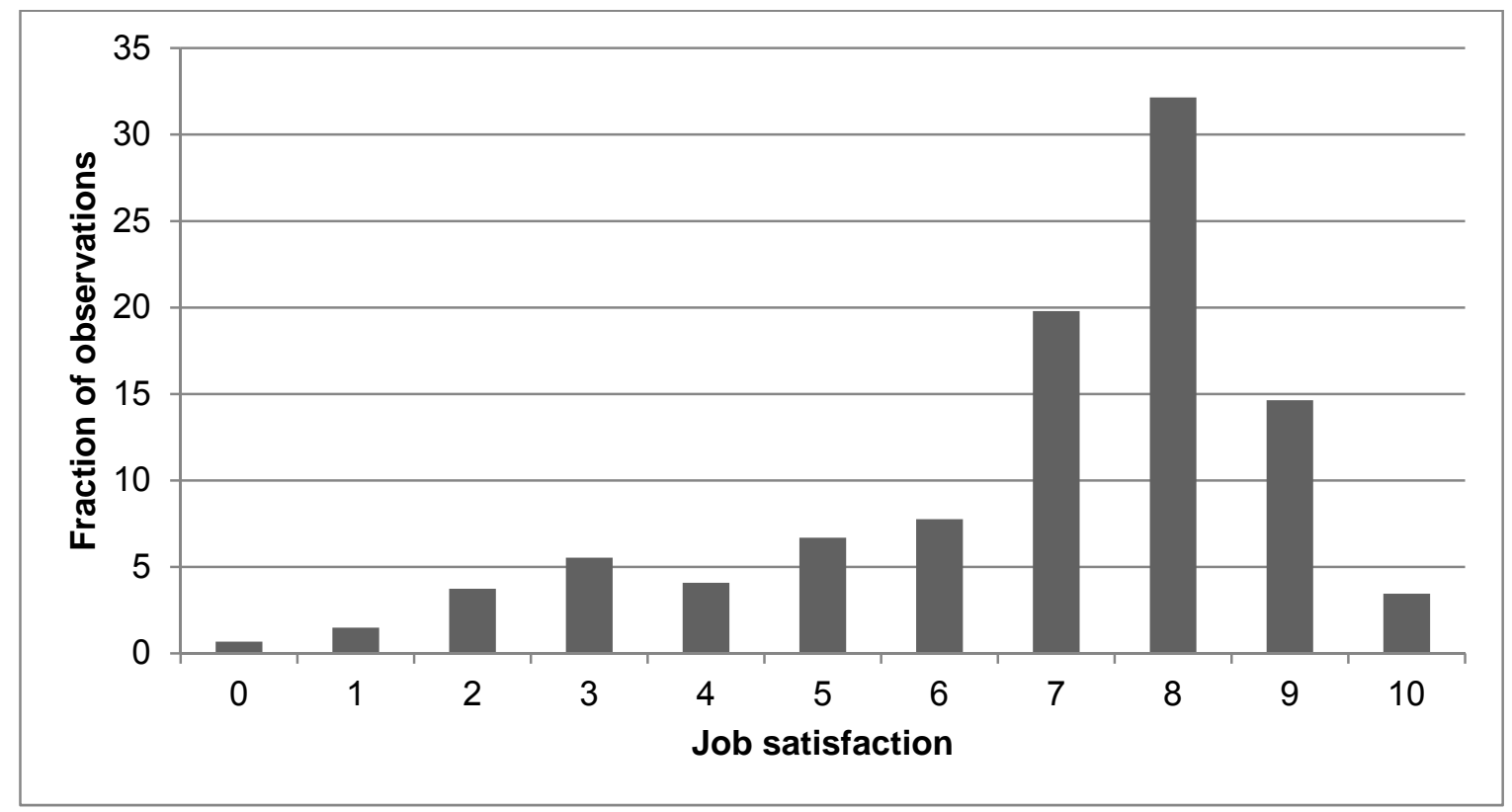


Table 2: Descriptive statistics

\begin{tabular}{|c|c|c|c|}
\hline Variable & $\mathbf{n}$ & Mean & $\begin{array}{l}\text { Standard } \\
\text { deviation }\end{array}$ \\
\hline Job satisfaction & 14,773 & 6.84 & 2.14 \\
\hline Total Compensation in $\mathrm{t}$ (in $1,000 €$ ) & 14,773 & 121.33 & 50.54 \\
\hline Total Compensation in $\mathrm{t}-1$ (in $1,000 €$ ) & 7,347 & 118.85 & 43.18 \\
\hline Fixed Salaries in $\mathrm{t}$ (in $1,000 €$ ) & 14,773 & 95.92 & 26.31 \\
\hline Fixed Salaries in $\mathrm{t}-1$ (in $1,000 €$ ) & 7,347 & 94.72 & 24.39 \\
\hline Bonus Payments in $\mathrm{t}$ (in $1,000 €$ ) & 14,773 & 19.23 & 18.76 \\
\hline Bonus Payments in $\mathrm{t}-1$ (in $1,000 €$ ) & 7,347 & 17.66 & 15.73 \\
\hline Female (dummy, 1=yes) & 14,773 & 0.100 & \\
\hline Being in Relationship (dummy, 1=yes) & 14,773 & 0.919 & \\
\hline Children in household (dummy, 1=yes) & 14,773 & 0.662 & \\
\hline Distance to workplace (in km) & 14,773 & 23.54 & 23.67 \\
\hline Tenure (in years) & 14,773 & 15.67 & 8.63 \\
\hline Experience (in years) & 14,773 & 21.99 & 7.62 \\
\hline $\begin{array}{l}\text { Firm size (number of employees) } \\
\leq 100 \\
101-300 \\
301-1,000 \\
1,001-2,000 \\
2,001-5,000 \\
5,001-10,000 \\
10,001-30,000 \\
>30,000\end{array}$ & $\begin{array}{c}545 \\
652 \\
1,514 \\
1,487 \\
1,879 \\
1,781 \\
3,908 \\
3,007\end{array}$ & $\begin{array}{l}0.037 \\
0.043 \\
0.103 \\
0.101 \\
0.127 \\
0.121 \\
0.265 \\
0.204\end{array}$ & \\
\hline $\begin{array}{l}\text { Hierarchical Level } \\
\text { Level } 1 \text { (top management) } \\
\text { Level } 2 \\
\text { Level } 3 \\
\text { Level } 4\end{array}$ & $\begin{array}{c}264 \\
2,066 \\
7,855 \\
4,588\end{array}$ & $\begin{array}{l}0.018 \\
0.140 \\
0.532 \\
0.311\end{array}$ & \\
\hline $\begin{array}{l}\frac{Y e a r}{2008} \\
2009 \\
2010 \\
2011\end{array}$ & $\begin{array}{l}3,617 \\
3,763 \\
3,696 \\
3.697\end{array}$ & $\begin{array}{l}0.245 \\
0.255 \\
0.250 \\
0.250\end{array}$ & \\
\hline
\end{tabular}


Figure 2: Distribution of differences in job satisfaction over time

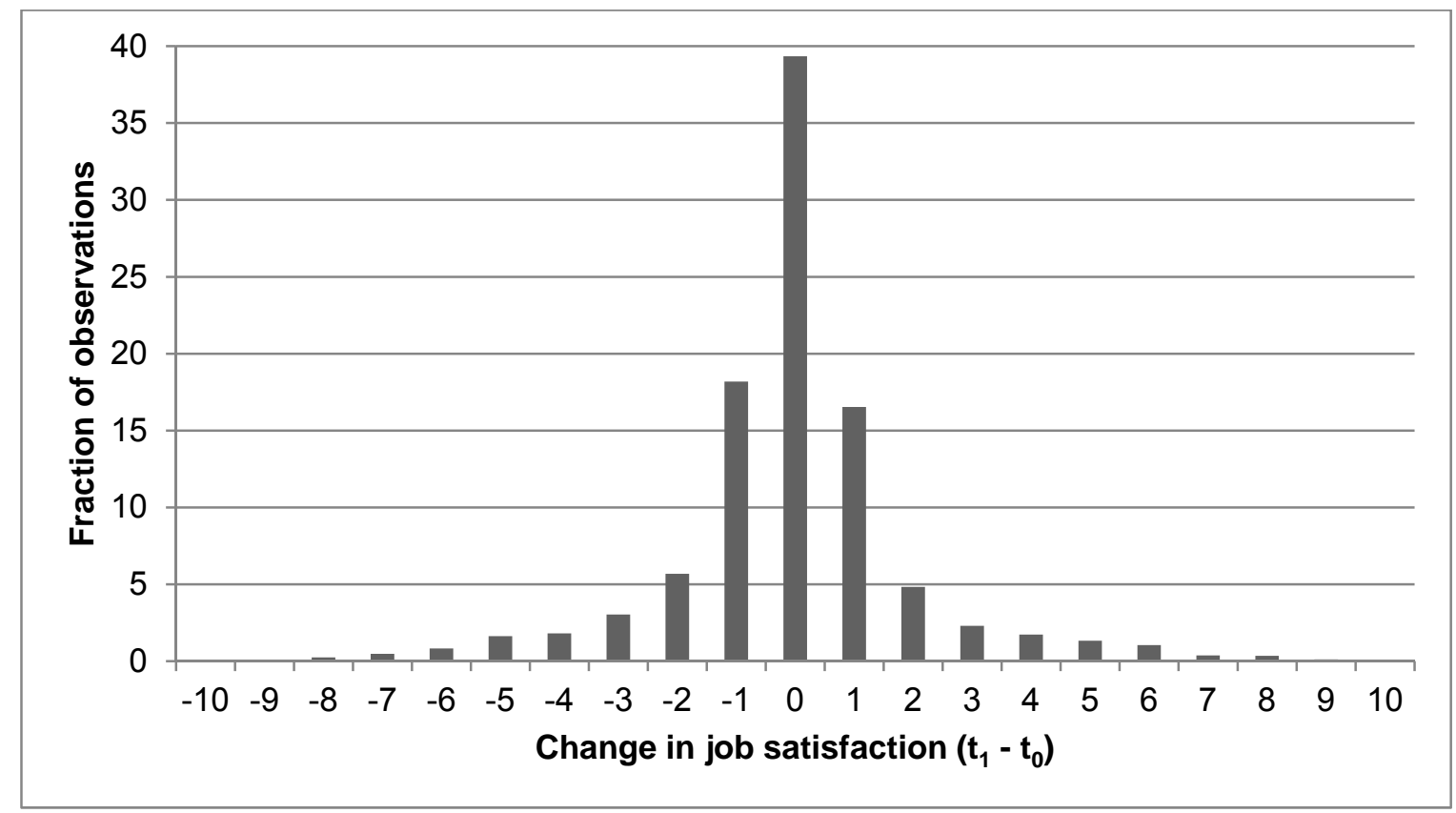

Figure 3: Status quo preferences and loss aversion

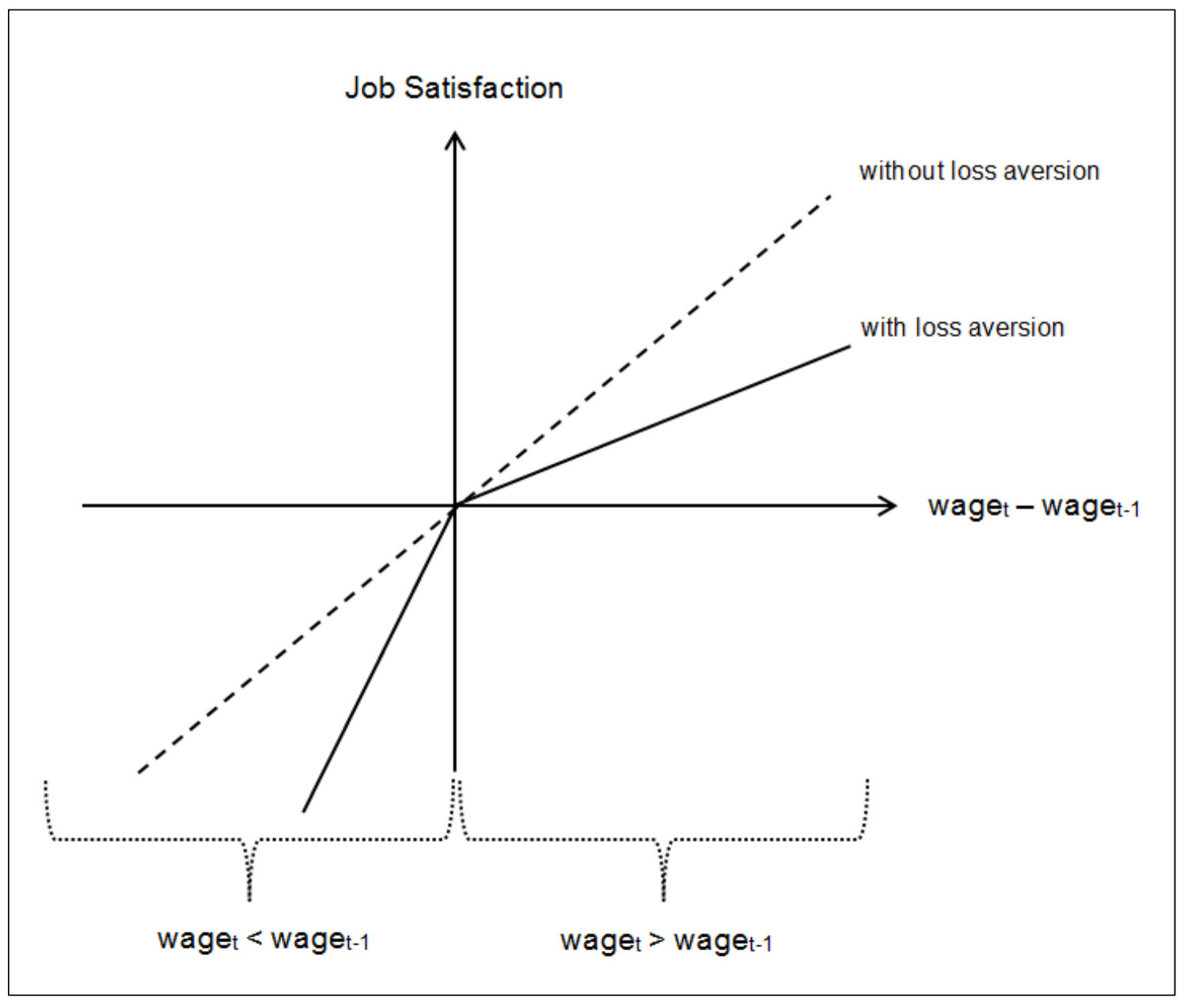


Table 3: Comparisons with the hitherto status quo (absolute differences)

\begin{tabular}{|c|c|c|c|c|c|c|}
\hline & \multicolumn{6}{|c|}{ Dependent variable: job satisfaction } \\
\hline & $\begin{array}{c}\text { (1) } \\
\text { Total OLS }\end{array}$ & $\begin{array}{c}(2) \\
\text { Total RE }\end{array}$ & $\begin{array}{c}(3) \\
\text { Total FE }\end{array}$ & $\begin{array}{c}(4) \\
\text { Fixed/Bonus OLS }\end{array}$ & $\begin{array}{c}\text { (5) } \\
\text { Fix/Bonus RE }\end{array}$ & $\begin{array}{c}(6) \\
\text { Fix/Bonus FE }\end{array}$ \\
\hline $\begin{array}{l}\text { Total Compensation }_{\mathrm{t}} \\
\text { Total Compensation }_{\mathrm{t}-1}\end{array}$ & $\begin{array}{c}0.0038^{* * *}(0.0011) \\
-0.0010(0.0013)\end{array}$ & $\begin{array}{c}0.0029^{* * *}(0.0009) \\
0.0003(0.0011)\end{array}$ & $\begin{array}{c}0.0009(0.0012) \\
-0.0007(0.0018)\end{array}$ & & & \\
\hline $\begin{array}{l}\text { Fixed Salary } \mathrm{t}_{\mathrm{t}} \\
\text { Fixed Salary } \mathrm{t}_{\mathrm{t}-1}\end{array}$ & & & & $\begin{array}{l}0.0120^{\star \star *}(0.0039) \\
-0.0082^{* *}(0.0040)\end{array}$ & $\begin{array}{l}0.0082^{* *}(0.0036) \\
-0.0051(0.0036)\end{array}$ & $\begin{array}{c}0.0043(0.0067) \\
-0.0040(0.0050)\end{array}$ \\
\hline $\begin{array}{l}\text { Bonus }_{t} \\
\text { Bonus Payment } t_{t-1}\end{array}$ & & & & $\begin{array}{c}0.0079^{* \star *}(0.0026) \\
-0.0021(0.0026)\end{array}$ & $\begin{array}{c}0.0059^{* \star *}(0.0022) \\
0.0025(0.0022)\end{array}$ & $\begin{array}{l}0.0038(0.0032) \\
0.0056(0.0036)\end{array}$ \\
\hline Female (dummy) & $-0.0085(0.0913)$ & $-0.0272(0.1113)$ & & $-0.0024(0.0916)$ & $-0.0242(0.1116)$ & \\
\hline In Relationship (dummy) & $0.2032^{* \star}(0.1006)$ & $0.2324^{* *}(0.1135)$ & $-0.0255(0.2199)$ & $0.1898^{*}(0.1002)$ & $0.2216^{*}(0.1131)$ & $-0.0281(0.2187)$ \\
\hline Children in Household (1=yes) & $0.0056(0.0602)$ & $-0.0158(0.0686)$ & $-0.1689(0.1611)$ & $0.0040(0.0601)$ & $-0.0194(0.0686)$ & $-0.1794(0.1613)$ \\
\hline Distance to workplace (in km) & $-0.0036^{* * *}(0.0012)$ & $-0.0016(0.0013)$ & $0.0055^{\star}(0.0030)$ & $-0.0036^{* * *}(0.0012)$ & $-0.0016(0.0013)$ & $0.0056^{*}(0.0030)$ \\
\hline Up to 100 employees & $-0.2631(0.1839)$ & $-0.3507(0.2337)$ & $-0.2810(0.8106)$ & $-0.2270(0.1841)$ & $-0.3281(0.2346)$ & $-0.2625(0.8132)$ \\
\hline 1-300 employees & $-0.3496^{\star *}(0.1692)$ & $-0.3157(0.2078)$ & $0.0361(0.4761)$ & $-0.3256^{*}(0.1686)$ & $-0.2936(0.2072)$ & $0.0482(0.4788)$ \\
\hline 301-1,000 employees & $0.1170(0.1118)$ & $0.0097(0.1258)$ & $-0.0071(0.2611)$ & $0.1254(0.1119)$ & $0.0190(0.1256)$ & $-0.0035(0.2602)$ \\
\hline $1,001-2,000$ employees & --- & --- & --- & --- & --- & --- \\
\hline $2,001-5,000$ employees & $-0.0109(0.1057)$ & $-0.0119(0.1163)$ & $-0.0130(0.2187)$ & $-0.0198(0.1057)$ & $-0.0191(0.1163)$ & $-0.0114(0.2178)$ \\
\hline $5,001-10,000$ employees & $-0.2019^{*}(0.1109)$ & $-0.1874(0.1216)$ & $-0.2192(0.2391)$ & $-0.2225^{\star *}(0.1110)$ & $-0.2077^{*}(0.1217)$ & $-0.2147(0.2372)$ \\
\hline At least 30,001 employees & $0.4826^{\star * *}(0.0968)$ & $0.4290^{* * *}(0.1096)$ & $0.0965(0.2652)$ & $0.4644^{* * *}(0.0988)$ & $0.3957^{\star \star *}(0.1112)$ & $0.1003(0.2645)$ \\
\hline Tenure (in years) & $-0.0007(0.0053)$ & $-0.0045(0.0064)$ & $-0.0627^{* \star}(0.0244)$ & $-0.0005(0.0053)$ & $-0.0044(0.0064)$ & $-0.0616^{\star *}(0.0242)$ \\
\hline Experience (in years) & $-0.0227^{\star * *}(0.0061)$ & $-0.0189^{* \star *}(0.0072)$ & $-0.0183(0.0312)$ & $-0.0237^{\star \star *}(0.0064)$ & $-0.0194^{* * *}(0.0075)$ & $-0.0188(0.0312)$ \\
\hline Level 1 (Top Management) & $0.6822^{* *}(0.2730)$ & $0.6975^{\star *}(0.3292)$ & $0.2949(0.7344)$ & $0.5545^{\star *}(0.2754)$ & $0.5923^{*}(0.3270)$ & $0.2529(0.7299)$ \\
\hline Level 2 & $0.3040^{* * *}(0.0881)$ & $0.2885^{\star \star *}(0.0960)$ & $0.1197(0.1795)$ & $0.2679^{\star \star \star}(0.0882)$ & $0.2634^{\star * *}(0.0953)$ & $0.1276(0.1781)$ \\
\hline Level 3 & --- & -- & -- & --- & --- & --- \\
\hline Level 4 & $-0.3142^{* * *}(0.0635)$ & $-0.3167^{* * *}(0.0681)$ & $-0.3735^{* * *}(0.1108)$ & $-0.2783^{* * *}(0.0647)$ & $-0.2948^{* * *}(0.0690)$ & $-0.3770^{* \star *}(0.1107)$ \\
\hline 2009 & $0.0189(0.0617)$ & $0.0040(0.0457)$ & $-0.0637(0.0626)$ & $0.0159(0.0622)$ & $-0.0116(0.0467)$ & $-0.0848(0.0686)$ \\
\hline 2010 & --- & --- & --- & --- & --- & --- \\
\hline 2011 & $-0.0760(0.0620)$ & $-0.0726(0.0466)$ & $0.0147(0.0681)$ & $-0.1071^{*}(0.0639)$ & $-0.0906^{*}(0.0483)$ & $-0.0102(0.0755)$ \\
\hline Constant & $6.8319^{\star \star *}(0.1602)$ & $6.7295^{\star * *}(0.1806)$ & $8.4096^{\star * \star}(0.9267)$ & $6.7256^{\star * *}(0.1845)$ & $6.7006^{\star \star \star}(0.2079)$ & $8.2342^{* \star *}-12236$ \\
\hline Observations (persons) & 7,031 & $7,031(3,844)$ & $7,031(3,844)$ & 7,031 & $7,031(3,844)$ & $7,031(3,844)$ \\
\hline $\mathrm{R}^{2}$ (overall) & 0.0350 & 0.0339 & 0.0016 & 0.0371 & 0.0355 & 0.0042 \\
\hline
\end{tabular}

Notes: Robust standard errors in parentheses. All wages are divided by 1,000 . 
Table 4: Comparisons with the hitherto status quo (relative differences)

\begin{tabular}{|c|c|c|c|c|c|c|}
\hline & \multicolumn{6}{|c|}{ Dependent variable: job satisfaction } \\
\hline & $\begin{array}{c}\text { (1) } \\
\text { Total OLS }\end{array}$ & $\begin{array}{c}(2) \\
\text { Total RE }\end{array}$ & $\begin{array}{c}(3) \\
\text { Total FE }\end{array}$ & $\begin{array}{c}(4) \\
\text { Fix/Bonus OLS }\end{array}$ & $\begin{array}{c}\text { (5) } \\
\text { Fix/Bonus RE }\end{array}$ & $\begin{array}{c}\text { (6) } \\
\text { Fix/Bonus FE }\end{array}$ \\
\hline Total Compensation $_{t}$ & $0.0099^{* * *}(0.0021)$ & $0.0070^{* * *}(0.0018)$ & $0.4315(0.2896)$ & & & \\
\hline Total Compensation $\mathrm{t}_{\mathrm{t}-1}$ & $-0.0054^{\star * *}(0.0021)$ & $-0.0024(0.0017)$ & $0.0003(0.0028)$ & & & \\
\hline Fixed Salary ${ }_{t}$ & & & & $0.0085^{\star * *}(0.0028)$ & $0.0047^{\star \star}(0.0023)$ & $0.0021(0.0039)$ \\
\hline Fixed Salary $\mathrm{t}_{\mathrm{t}-1}$ & & & & $-0.0064^{\star *}(0.0026)$ & $-0.0043^{\star *}(0.0020)$ & $-0.0024(0.0029)$ \\
\hline Bonus $_{t}$ & & & & $0.0022^{\star \star \star}(0.0006)$ & $0.0015^{\star \star \star}(0.0005)$ & $0.0009(0.0008)$ \\
\hline Bonus Payment $t_{-1}$ & & & & $-0.0001(0.0006)$ & $0.0009^{*}(0.0005)$ & $0.0016^{* *}(0.0008)$ \\
\hline Female (dummy) & $0.0342(0.0968)$ & $-0.0068(0.1196)$ & & $0.0301(0.0971)$ & $-0.0169(0.1198)$ & \\
\hline In Relationship (dummy) & $0.1911^{*}(0.1077)$ & $0.1897(0.1185)$ & $-0.2402(0.2118)$ & $0.1816^{*}(0.1074)$ & $0.1885(0.1185)$ & $-0.2346(0.2119)$ \\
\hline Children in Household (1=yes) & $0.0180(0.0636)$ & $0.0142(0.0713)$ & $-0.1440(0.1542)$ & $0.0191(0.0636)$ & $0.0139(0.0713)$ & $-0.1474(0.1537)$ \\
\hline Distance to workplace (in km) & $-0.0037^{* * *}(0.0012)$ & $-0.0013(0.0014)$ & $0.0059^{*}(0.0030)$ & $-0.0037^{\star \star \star}(0.0012)$ & $-0.0013(0.0014)$ & $0.0059^{*}(0.0030)$ \\
\hline Up to 100 employees & $-0.1108(0.2173)$ & $-0.0811(0.2722)$ & $0.5678(0.9421)$ & $-0.0606(0.2167)$ & $-0.0532(0.2708)$ & $0.6272(0.9299)$ \\
\hline 1-300 employees & $-0.1370(0.1868)$ & $-0.0843(0.2133)$ & $0.5024(0.4239)$ & $-0.1114(0.1865)$ & $-0.0679(0.2124)$ & $0.4848(0.4217)$ \\
\hline 301-1,000 employees & $0.1544(0.1243)$ & $0.0296(0.1391)$ & $-0.1101(0.2769)$ & $0.1656(0.1244)$ & $0.0372(0.1390)$ & $-0.1168(0.2764)$ \\
\hline $1,001-2,000$ employees & $0.0000(0.0000)$ & --- & --- & --- & --- & --- \\
\hline 2,001-5,000 employees & $-0.0293(0.1148)$ & $-0.0309(0.1212)$ & $-0.1033(0.2063)$ & $-0.0320(0.1149)$ & $-0.0297(0.1216)$ & $-0.0996(0.2065)$ \\
\hline $5,001-10,000$ employees & $-0.2415^{\star \star}(0.1202)$ & $-0.2158^{*}(0.1275)$ & $-0.2985(0.2334)$ & $-0.2669^{* *}(0.1202)$ & $-0.2377^{*}(0.1276)$ & $-0.2923(0.2316)$ \\
\hline $10,001-30,000$ employees & $0.2283^{* *}(0.1017)$ & $0.1998^{*}(0.1124)$ & $-0.0756(0.2374)$ & $0.1872^{*}(0.1025)$ & $0.1731(0.1132)$ & $-0.0642(0.2364)$ \\
\hline At least 30,001 employees & $0.4542^{* * *}(0.1051)$ & $0.3948^{* * *}(0.1159)$ & $0.0313(0.2633)$ & $0.3994^{* * *}(0.1069)$ & $0.3368^{* * *}(0.1178)$ & $0.0329(0.2636)$ \\
\hline Tenure (in years) & $-0.0031(0.0056)$ & $-0.0068(0.0068)$ & $-0.0566^{* *}(0.0261)$ & $-0.0031(0.0056)$ & $-0.0067(0.0068)$ & $-0.0554^{\star \star}(0.0259)$ \\
\hline Experience (in years) & $-0.0212^{\star \star *}(0.0066)$ & $-0.0159^{\star *}(0.0079)$ & $0.0253(0.0280)$ & $-0.0207^{\star * *}(0.0068)$ & $-0.0142^{*}(0.0080)$ & $0.0242(0.0282)$ \\
\hline Level 1 (Top Management) & $0.5394^{*}(0.2979)$ & $0.5115(0.3328)$ & $0.0698(0.6576)$ & $0.4847(0.2960)$ & $0.4986(0.3290)$ & $0.0729(0.6492)$ \\
\hline Level 2 & $0.2827^{\star \star *}(0.0918)$ & $0.3128^{* * *}(0.0988)$ & $0.3020^{*}(0.1795)$ & $0.2759^{* * *}(0.0896)$ & $0.3247^{* * *}(0.0965)$ & $0.3130^{*}(0.1801)$ \\
\hline Level 3 & $0.0000(0.0000)$ & --- & --- & --- & --- & --- \\
\hline Level 4 & $-0.2826^{\star * *}(0.0697)$ & $-0.2823^{\star * *}(0.0734)$ & $-0.3606^{\star * *}(0.1141)$ & $-0.2579^{\star * *}(0.0706)$ & $-0.2749^{* * *}(0.0741)$ & $-0.3594^{\star * *}(0.1146)$ \\
\hline 2009 & $0.0138(0.0643)$ & $0.0107(0.0474)$ & $0.0091(0.0627)$ & $-0.0108(0.0647)$ & $-0.0189(0.0481)$ & $-0.0232(0.0652)$ \\
\hline 2010 & $0.0000(0.0000)$ & --- & --- & --- & --- & --- \\
\hline 2011 & $-0.1043(0.0656)$ & $-0.0869 *(0.0493)$ & $-0.0662(0.0739)$ & $-0.1113^{*}(0.0675)$ & $-0.0858^{\star}(0.0501)$ & $-0.0545(0.0731)$ \\
\hline Constant & $1.9141(1.5307)$ & $1.7939(1.6814)$ & $2.1056(5.3486)$ & $2.7780(1.9190)$ & $4.3411^{* *}(2.1013)$ & $5.5646(6.9088)$ \\
\hline Observations (persons) & 6,350 & $6,350(3,501)$ & $6,350(3,501)$ & 6,350 & $6,350(3,501)$ & $6,350(3,501)$ \\
\hline $\mathrm{R}^{2}$ (overall) & 0.0342 & 0.0326 & 0.0042 & 0.0356 & 0.0336 & 0.0053 \\
\hline
\end{tabular}

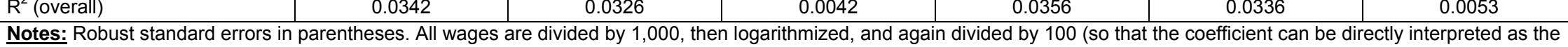
absolute effect on satisfaction. 
Table 5: Status quo preferences and loss aversion (absolute differences)

\begin{tabular}{|c|c|c|c|c|c|c|}
\hline & \multicolumn{6}{|c|}{ Dependent variable: job satisfaction } \\
\hline & $\begin{array}{c}\text { (1) } \\
\text { Total OLS }\end{array}$ & $\begin{array}{c}(2) \\
\text { Total RE }\end{array}$ & $\begin{array}{c}\text { (3) } \\
\text { Total FE }\end{array}$ & $\begin{array}{c}\text { (4) } \\
\text { Fix/Bonus OLS }\end{array}$ & $\begin{array}{c}\text { (5) } \\
\text { Fix/Bonus RE }\end{array}$ & $\begin{array}{c}(6) \\
\text { Fix/Bonus FE }\end{array}$ \\
\hline Total Compensation $_{t}$ & $0.0035^{\star \star \star}(0.0010)$ & $0.0032^{\star \star \star}(0.0011)$ & $-0.0018(0.0027)$ & & & \\
\hline Total Comp $p_{t}-$ Total Comp $p_{t-1}$ & $-0.0010(0.0018)$ & $-0.0004(0.0017)$ & $0.0040(0.0028)$ & & & \\
\hline$\left(\text { Total Comp } p_{t}-\text { Total Comp }_{\mathrm{t}-1}\right)^{\star}$ Decrease & $0.0049(0.0032)$ & $0.0002(0.0029)$ & $-0.0063(0.0041)$ & & & \\
\hline Fixed Salary $y_{t}$ & & & & $0.0038^{\star \star}(0.0019)$ & $0.0029(0.0022)$ & $0.0009(0.0083)$ \\
\hline Fixed Salary $\mathrm{t}_{\mathrm{t}}$ Fixed Salary $\mathrm{t}_{\mathrm{t}-1}$ & & & & $0.0131^{* *}(0.0053)$ & $0.0113^{\star \star}(0.0048)$ & $0.0112(0.0074)$ \\
\hline$\left(\text { Fixed Salary }_{t}-\text { Fixed Salary } y_{t-1}\right)^{*}$ Decrease & & & & $-0.0150(0.0093)$ & $-0.0183^{*}(0.0100)$ & $-0.0204(0.0136)$ \\
\hline Bonus $_{t}$ & & & & $0.0071^{* *}(0.0031)$ & $0.0095^{* * *}(0.0035)$ & $0.0108(0.0066)$ \\
\hline Bonus $_{t}-$ Bonus $_{t-1}$ & & & & $-0.0024(0.0039)$ & $-0.0056(0.0039)$ & $-0.0077(0.0063)$ \\
\hline$\left(\text { Bonus }_{t}-\text { Bonus }_{t-1}\right)^{*}$ Decrease & & & & $0.0087(0.0062)$ & $0.0059(0.0056)$ & $0.0036(0.0076)$ \\
\hline Female (dummy) & $-0.0064(0.0914)$ & $-0.0271(0.1113)$ & & $-0.0081(0.0917)$ & $-0.0285(0.1117)$ & \\
\hline In Relationship (dummy) & $0.2007^{\star \star}(0.1006)$ & $0.2323^{\star *}(0.1135)$ & $-0.0284(0.2197)$ & $0.1894^{*}(0.1002)$ & $0.2197^{*}(0.1130)$ & $-0.0282(0.2171)$ \\
\hline Children in Household (1=yes) & $0.0052(0.0602)$ & $-0.0158(0.0686)$ & $-0.1703(0.1609)$ & $0.0034(0.0601)$ & $-0.0191(0.0686)$ & $-0.1762(0.1622)$ \\
\hline Distance to workplace (in km) & $-0.0036^{* * *}(0.0012)$ & $-0.0016(0.0013)$ & $0.0055^{\star}(0.0030)$ & $-0.0036^{\star \star *}(0.0012)$ & $-0.0015(0.0013)$ & $0.0056^{*}(0.0030)$ \\
\hline Up to 100 employees & $-0.2611(0.1843)$ & $-0.3505(0.2339)$ & $-0.2814(0.8096)$ & $-0.2323(0.1841)$ & $-0.3271(0.2332)$ & $-0.2481(0.8027)$ \\
\hline 1-300 employees & $-0.3499^{\star *}(0.1691)$ & $-0.3157(0.2078)$ & $0.0317(0.4742)$ & $-0.3349^{* *}(0.1685)$ & $-0.2957(0.2055)$ & $0.0671(0.4692)$ \\
\hline 301-1,000 employees & $0.1141(0.1117)$ & $0.0097(0.1258)$ & $-0.0095(0.2609)$ & $0.1228(0.1119)$ & $0.0197(0.1251)$ & $0.0073(0.2570)$ \\
\hline 2,001-5,000 employees & $-0.0161(0.1057)$ & $-0.0120(0.1163)$ & $-0.0219(0.2184)$ & $-0.0258(0.1054)$ & $-0.0210(0.1160)$ & $-0.0061(0.2166)$ \\
\hline $5,001-10,000$ employees & $-0.2072^{*}(0.1108)$ & $-0.1875(0.1216)$ & $-0.2271(0.2388)$ & $-0.2288^{* *}(0.1108)$ & $-0.2131^{*}(0.1213)$ & $-0.2070(0.2354)$ \\
\hline 10,001-30,000 employees & $0.2423^{\star \star *}(0.0930)$ & $0.2080^{* *}(0.1058)$ & $-0.0553(0.2430)$ & $0.2037^{* *}(0.0937)$ & $0.1692(0.1063)$ & $-0.0267(0.2392)$ \\
\hline At least 30,001 employees & $0.4760^{\star * *}(0.0967)$ & $0.4288^{\star \star *}(0.1096)$ & $0.0891(0.2651)$ & $0.4588^{\star \star *}(0.0986)$ & $0.3909^{\star \star *}(0.1108)$ & $0.1131(0.2618)$ \\
\hline Tenure (in years) & $-0.0010(0.0053)$ & $-0.0045(0.0064)$ & $-0.0614^{* *}(0.0244)$ & $-0.0001(0.0053)$ & $-0.0037(0.0063)$ & $-0.0574^{* \star}(0.0238)$ \\
\hline Experience (in years) & $-0.0234^{* * *}(0.0061)$ & $-0.0189^{* * *}(0.0073)$ & $-0.0186(0.0311)$ & $-0.0239^{* * *}(0.0064)$ & $-0.0198^{* * *}(0.0075)$ & $-0.0185(0.0312)$ \\
\hline Level 1 (Top Management) & $0.6648^{\star \star}(0.2737)$ & $0.6968^{\star *}(0.3295)$ & $0.3074(0.7364)$ & $0.5472^{\star *}(0.2771)$ & $0.5819^{*}(0.3263)$ & $0.2484(0.7252)$ \\
\hline Level 2 & $0.3039^{* * *}(0.0880)$ & $0.2884^{* * *}(0.0959)$ & $0.1152(0.1794)$ & $0.2673^{* * *}(0.0887)$ & $0.2610^{* * *}(0.0956)$ & $0.1386(0.1772)$ \\
\hline Level 3 & $0.0000(0.0000)$ & --- & --- & -- & --- & --- \\
\hline Level 4 & $-0.3057^{* * *}(0.0639)$ & $-0.3165^{\star \star *}(0.0683)$ & $-0.3724^{* * *}(0.1108)$ & $-0.2750^{\star * *}(0.0647)$ & $-0.2916^{\star * *}(0.0690)$ & $-0.3765^{\star * \star}(0.1105)$ \\
\hline 2009 & $0.0217(0.0616)$ & $0.0041(0.0457)$ & $-0.0688(0.0627)$ & $0.0170(0.0622)$ & $-0.0108(0.0467)$ & $-0.0789(0.0684)$ \\
\hline 2010 & $0.0000(0.0000)$ & --- & --- & --- & --- & --- \\
\hline 2011 & $-0.0710(0.0619)$ & $-0.0724(0.0467)$ & $0.0167(0.0684)$ & $-0.1007(0.0639)$ & $-0.0890^{*}(0.0482)$ & $-0.0219(0.0742)$ \\
\hline Constant & $6.8000^{\star \star \star}(0.1627)$ & $6.7282^{\star \star \star}(0.1829)$ & $8.6101^{\star \star \star}(0.9390)$ & $6.7081^{\star \star \star}(0.1855)$ & $6.6808^{\star \star \star}(0.2083)$ & $8.0292^{\star \star \star}-11925$ \\
\hline Observations (persons) & 7,031 & $7,031(3,844)$ & $7,031(3,844)$ & 7,031 & $7,031(3,844)$ & $7,031(3,844)$ \\
\hline $\mathrm{R}^{2}$ (overall) & 0.0353 & 0.0339 & 0.0009 & 0.0377 & 0.0361 & 0.0059 \\
\hline
\end{tabular}

Notes: Robust standard errors in parentheses. All wages are divided by 1,000 . 
Table 6: Social comparisons on the market level (absolute differences)

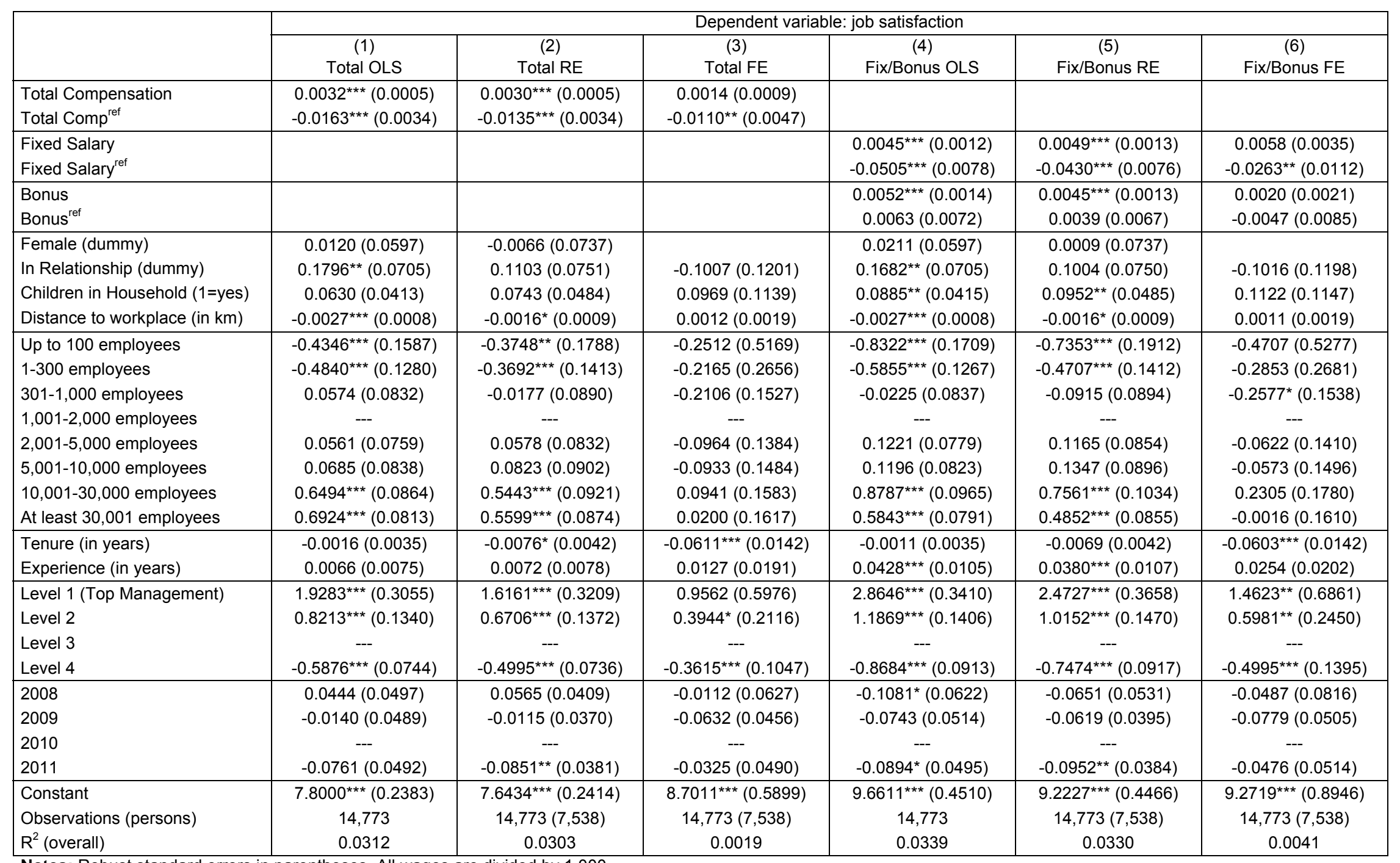

Notes: Robust standard errors in parentheses. All wages are divided by 1,000 . 
Table 7: Social comparisons on the market level (relative differences)

\begin{tabular}{|c|c|c|c|c|c|c|}
\hline & \multicolumn{6}{|c|}{ Dependent variable: job satisfaction } \\
\hline & $\begin{array}{c}\text { (1) } \\
\text { Total OLS }\end{array}$ & $\begin{array}{c}\text { (2) } \\
\text { Total RE }\end{array}$ & $\begin{array}{c}(3) \\
\text { Total FE }\end{array}$ & $\begin{array}{c}(4) \\
\text { Fix/Bonus OLS }\end{array}$ & $\begin{array}{c}\text { (5) } \\
\text { Fix/Bonus RE }\end{array}$ & $\begin{array}{c}\text { (6) } \\
\text { Fix/Bonus FE }\end{array}$ \\
\hline Total Compensation & $0.0056^{\star * \star}(0.0009)$ & $0.0056^{* * *}(0.0010)$ & $0.0054^{\star * *}(0.0020)$ & & & \\
\hline Total Comp ${ }^{\text {ref }}$ & $-0.0287^{* * *}(0.0041)$ & $-0.0237^{* * *}(0.0041)$ & $-0.01343^{* *}(0.0060)$ & & & \\
\hline Fixed Salary & & & & $0.0034^{\star * *}(0.0011)$ & $0.0031^{* * *}(0.0012)$ & $0.0032(0.0023)$ \\
\hline Fixed Salary ${ }^{\text {ref }}$ & & & & $-0.0437^{\star \star *}(0.0065)$ & $-0.03783^{* \star *}(0.0063)$ & $-0.0171^{*}(0.0102)$ \\
\hline Bonus & & & & $0.0017^{* \star *}(0.0003)$ & $0.0015^{\star \star \star}(0.0003)$ & $0.0007(0.0005)$ \\
\hline Bonus $^{\text {ref }}$ & & & & $0.0006(0.0018)$ & $0.0001(0.0015)$ & $-0.0011(0.0018)$ \\
\hline Female (dummy) & $0.0293(0.0618)$ & $-0.0092(0.0764)$ & & $0.0289(0.0617)$ & $-0.0126(0.0763)$ & \\
\hline In Relationship (dummy) & $0.1690^{\star \star}(0.0731)$ & $0.0794(0.0768)$ & $-0.1930(0.1214)$ & $0.1626^{* \star}(0.0730)$ & $0.0752(0.0766)$ & $-0.1938(0.1213)$ \\
\hline Children in Household (1=yes) & $0.1010^{\star \star}(0.0431)$ & $0.1089^{\star \star}(0.0502)$ & $0.1137(0.1177)$ & $0.1209^{\star * \star}(0.0433)$ & $0.1334^{* * *}(0.0504)$ & $0.1234(0.1185)$ \\
\hline Distance to workplace (in km) & $-0.0024^{* * *}(0.0008)$ & $-0.0011(0.0010)$ & $0.0017(0.0019)$ & $-0.0024^{* * *}(0.0008)$ & $-0.0011(0.0010)$ & $0.0017(0.0019)$ \\
\hline Up to 100 employees & $-0.7131^{* * *}(0.1723)$ & $-0.5855^{\star \star \star}(0.1986)$ & $0.0676(0.5845)$ & $-0.7632^{* \star *}(0.1736)$ & $-0.7204^{* * *}(0.1994)$ & $-0.0283(0.5934)$ \\
\hline 1-300 employees & $-0.5611^{* \star *}(0.1353)$ & $-0.3975^{\star \star \star}(0.1446)$ & $0.0221(0.2740)$ & $-0.4769^{\star \star \star}(0.1409)$ & $-0.3758^{* \star}(0.1474)$ & $0.0001(0.2760)$ \\
\hline 301-1,000 employees & $-0.0120(0.0878)$ & $-0.0664(0.0933)$ & $-0.2170(0.1649)$ & $0.0037(0.0905)$ & $-0.0766(0.0950)$ & $-0.2369(0.1664)$ \\
\hline 1,001-2,000 employees & --- & --- & --- & --- & --- & --- \\
\hline 2,001-5,000 employees & $0.0353(0.0793)$ & $0.0479(0.0849)$ & $-0.1047(0.1391)$ & $0.0805(0.0818)$ & $0.0874(0.0878)$ & $-0.1019(0.1436)$ \\
\hline $5,001-10,000$ employees & $0.1196(0.0871)$ & $0.1319(0.0929)$ & $-0.1071(0.1558)$ & $0.0655(0.0849)$ & $0.1091(0.0909)$ & $-0.1217(0.1560)$ \\
\hline 10,001-30,000 employees & $0.7391^{\star \star *}(0.0906)$ & $0.6225^{\star \star \star}(0.0957)$ & $0.1027(0.1663)$ & $0.7825^{\star \star *}(0.0907)$ & $0.7026^{\star * *}(0.0980)$ & $0.1382(0.1795)$ \\
\hline At least 30,001 employees & $0.7600^{\star * *}(0.0849)$ & $0.6201^{* * *}(0.0903)$ & $0.0399(0.1674)$ & $0.5114^{\star * *}(0.0958)$ & $0.4516^{\star * *}(0.0938)$ & $-0.0142(0.1671)$ \\
\hline Tenure (in years) & $-0.0028(0.0036)$ & $-0.0080^{*}(0.0044)$ & $-0.0581^{* * *}(0.0156)$ & $-0.0026(0.0036)$ & $-0.0074^{*}(0.0044)$ & $-0.0576^{* * *}(0.0155)$ \\
\hline Experience (in years) & $0.0266^{* * *}(0.0084)$ & $0.0229^{* * *}(0.0088)$ & $0.0328^{*}(0.0196)$ & $0.0445^{\star \star \star}(0.0094)$ & $0.0423^{* * *}(0.0101)$ & $0.0356^{*}(0.0211)$ \\
\hline Level 1 (Top Management) & $2.1440^{\star * \star}(0.2825)$ & $1.7615^{\star * \star}(0.3020)$ & $0.7126(0.5589)$ & $2.3402^{\star \star \star}(0.2753)$ & $2.0909^{* * \star}(0.3034)$ & $0.8424(0.5950)$ \\
\hline Level 2 & $1.0262^{* * *}(0.1232)$ & $0.8592^{* * *}(0.1280)$ & $0.4644^{* \star}(0.2062)$ & $1.0764^{\star \star \star}(0.1136)$ & $0.9795^{\star * \star}(0.1218)$ & $0.5092^{\star \star}(0.2213)$ \\
\hline Level 3 & --- & --- & --- & --- & --- & --- \\
\hline Level 4 & $-0.7701^{* * *}(0.0855)$ & $-0.6381^{* * *}(0.0846)$ & $-0.4047^{* * *}(0.1208)$ & $-0.8605^{\star \star \star}(0.0863)$ & $-0.7665^{\star \star \star}(0.0889)$ & $-0.4528^{\star \star \star}(0.1448)$ \\
\hline 2008 & $0.0436(0.0509)$ & $0.0561(0.0422)$ & $0.0282(0.0657)$ & $-0.1208^{*}(0.0708)$ & $-0.0724(0.0586)$ & $-0.0175(0.0842)$ \\
\hline 2009 & $-0.0120(0.0501)$ & $0.0009(0.0381)$ & $-0.0101(0.0472)$ & $-0.0631(0.0533)$ & $-0.0421(0.0409)$ & $-0.0297(0.0516)$ \\
\hline 2010 & --- & --- & --- & --- & --- & --- \\
\hline 2011 & $-0.0953^{*}(0.0503)$ & $-0.1020^{\star \star *}(0.0390)$ & $-0.0905^{*}(0.0527)$ & $-0.1112^{* *}(0.0506)$ & $-0.1118^{\star \star *}(0.0393)$ & $-0.0719(0.0522)$ \\
\hline Constant & $32.743^{\star \star \star}(4.4190)$ & $27.109^{\star \star \star}(4.4247)$ & $16.448^{* \star}(6.7609)$ & $49.544^{\star \star \star}(6.1771)$ & $44.023^{* * *}(6.2150)$ & $23.487^{* \star}(10.655)$ \\
\hline Observations (persons) & 13,953 & $13,953(7,205)$ & $13,953(7,205)$ & 13,953 & $13,953(7,205)$ & $13,953(7,205)$ \\
\hline $\mathrm{R}^{2}$ (overall) & 0.0315 & 0.0305 & 0.0044 & 0.0335 & 0.0327 & 0.0037 \\
\hline
\end{tabular}

Notes: Robust standard errors in parentheses. All wages are divided by 1,000, then logarithmized, and again divided by 100 (so that the coefficient can be directly interpreted as the absolute effect on satisfaction). 
Table 8: Social comparisons and loss aversion (market level, absolute differences)

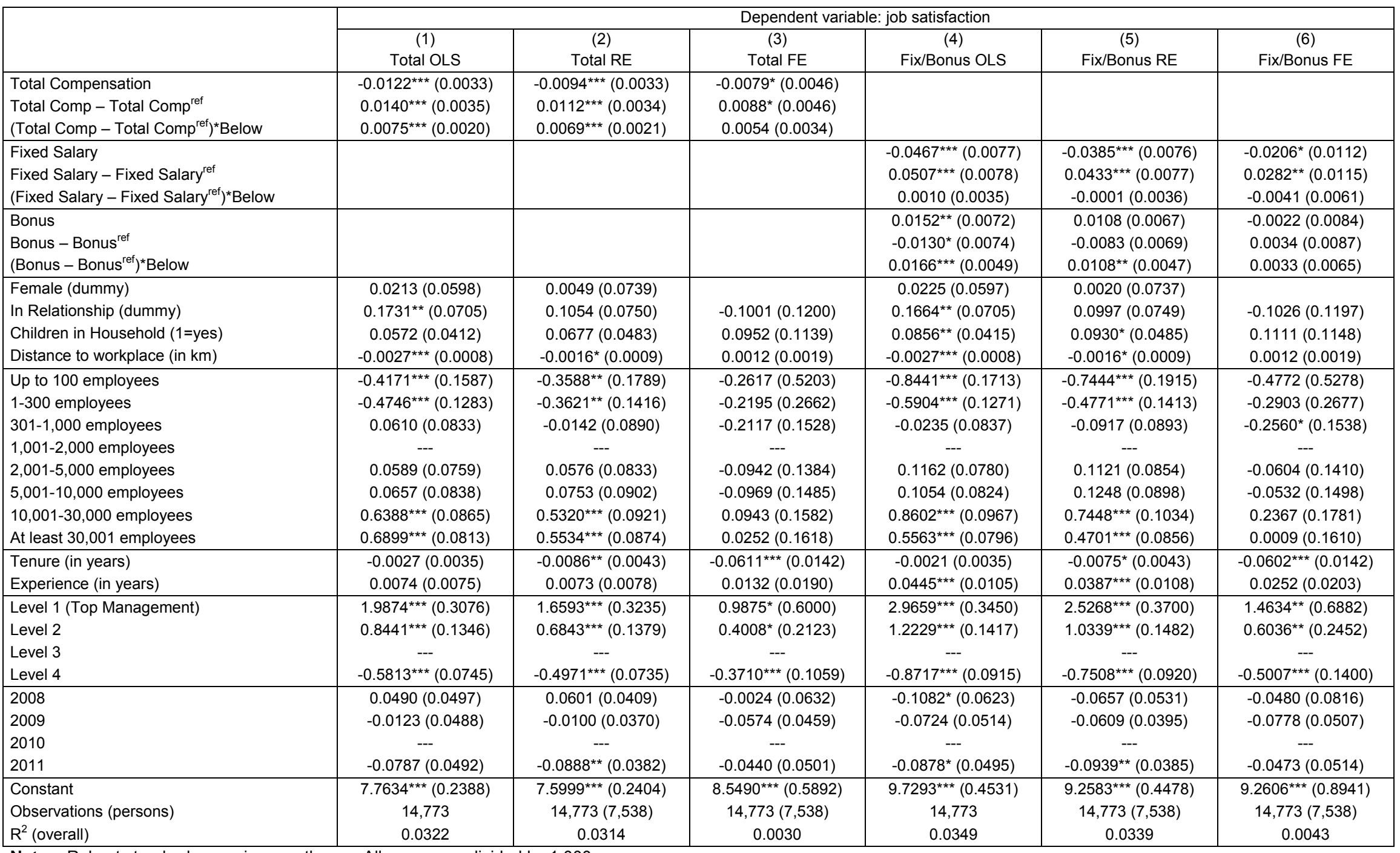

Notes: Robust standard errors in parentheses. All wages are divided by 1,000 . 
Table 9: Social comparisons on the market level (wage ranks)

\begin{tabular}{|c|c|c|c|c|c|c|}
\hline & \multicolumn{6}{|c|}{ Dependent variable: job satisfaction } \\
\hline & $\begin{array}{c}\text { (1) } \\
\text { Total OLS }\end{array}$ & $\begin{array}{c}(2) \\
\text { Total RE }\end{array}$ & $\begin{array}{c}\text { (3) } \\
\text { Total FE }\end{array}$ & $\begin{array}{c}(4) \\
\text { Fix/Bonus OLS }\end{array}$ & $\begin{array}{c}\text { (5) } \\
\text { Fix/Bonus RE }\end{array}$ & $\begin{array}{c}\text { (6) } \\
\text { Fix/Bonus FE }\end{array}$ \\
\hline $\begin{array}{l}\text { Total Compensation } \\
\text { Total Compensation }\end{array}$ & $\begin{array}{c}0.0005(0.0006) \\
0.0044^{\star * *}(0.0008)\end{array}$ & $\begin{array}{c}0.0009(0.0006) \\
0.0038^{\star * *}(0.0008)\end{array}$ & $\begin{array}{c}0.0004(0.0009) \\
0.0026^{* *}(0.0013)\end{array}$ & & & \\
\hline $\begin{array}{l}\text { Fixed Salary } \\
\text { Fixed Salary }\end{array}$ & & & & $\begin{array}{c}-0.0008(0.0018) \\
0.0027^{* * *}(0.0010)\end{array}$ & $\begin{array}{c}0.0005(0.0019) \\
0.0023^{\star *}(0.0010)\end{array}$ & $\begin{array}{l}0.0034(0.0038) \\
0.0013(0.0015)\end{array}$ \\
\hline $\begin{array}{l}\text { Bonus } \\
\text { Bonus }^{\text {rank }}\end{array}$ & & & & $\begin{array}{c}0.0011(0.0016) \\
0.0038^{\star \star *}(0.0008)\end{array}$ & $\begin{array}{c}0.0020(0.0015) \\
0.0022^{\star \star *}(0.0008)\end{array}$ & $\begin{array}{c}0.0018(0.0026) \\
-0.0003(0.0011)\end{array}$ \\
\hline Female (dummy) & $0.0196(0.0599)$ & $0.0026(0.0740)$ & & $0.0152(0.0599)$ & $-0.0010(0.0739)$ & \\
\hline In Relationship (dummy) & $0.1648^{* *}(0.0706)$ & $0.0962(0.0749)$ & $-0.1103(0.1194)$ & $0.1676^{\star *}(0.0705)$ & $0.0995(0.0749)$ & $-0.1070(0.1198)$ \\
\hline Children in Household (1=yes) & $0.0397(0.0411)$ & $0.0534(0.0482)$ & $0.0846(0.1135)$ & $0.0380(0.0412)$ & $0.0516(0.0482)$ & $0.0842(0.1137)$ \\
\hline Distance to workplace (in km) & $-0.0027^{* * *}(0.0008)$ & $-0.0016^{*}(0.0009)$ & $0.0012(0.0019)$ & $-0.0028^{* * *}(0.0008)$ & $-0.0016^{*}(0.0009)$ & $0.0013(0.0019)$ \\
\hline Up to 100 employees & $-0.0129(0.1204)$ & $-0.0325(0.1488)$ & $0.0213(0.5132)$ & $-0.0380(0.1226)$ & $-0.0338(0.1510)$ & $0.0675(0.5134)$ \\
\hline 1-300 employees & $-0.2540^{\star \star}(0.1147)$ & $-0.1857(0.1302)$ & $-0.0688(0.2579)$ & $-0.2639^{* *}(0.1150)$ & $-0.1831(0.1307)$ & $-0.0407(0.2596)$ \\
\hline 301-1,000 employees & $0.1684^{* *}(0.0786)$ & $0.0715(0.0844)$ & $-0.1440(0.1500)$ & $0.1645^{\star \star}(0.0788)$ & $0.0729(0.0846)$ & $-0.1310(0.1507)$ \\
\hline $1,001-2,000$ employees & --- & -- & --- & --- & --- & --- \\
\hline 2,001-5,000 employees & $0.0292(0.0756)$ & $0.0318(0.0830)$ & $-0.1148(0.1382)$ & $0.0321(0.0756)$ & $0.0325(0.0831)$ & $-0.1145(0.1383)$ \\
\hline $5,001-10,000$ employees & $-0.0591(0.0774)$ & $-0.0236(0.0846)$ & $-0.1720(0.1422)$ & $-0.0532(0.0775)$ & $-0.0247(0.0849)$ & $-0.1891(0.1422)$ \\
\hline 10,001-30,000 employees & $0.4245^{\star * *}(0.0662)$ & $0.3636^{* * *}(0.0744)$ & $-0.0347(0.1425)$ & $0.4362^{\star * *}(0.0678)$ & $0.3648^{\star * *}(0.0760)$ & $-0.0635(0.1438)$ \\
\hline At least 30,001 employees & $0.5301^{\star \star *}(0.0684)$ & $0.4228^{\star \star \star}(0.0765)$ & $-0.0822(0.1528)$ & $0.5354^{\star \star \star}(0.0685)$ & $0.4226^{\star \star \star}(0.0769)$ & $-0.1205(0.1553)$ \\
\hline Tenure (in years) & $-0.0034(0.0035)$ & $-0.0092^{* *}(0.0043)$ & $-0.0613^{* * *}(0.0142)$ & $-0.0037(0.0035)$ & $-0.0092^{* *}(0.0042)$ & $-0.0607^{* * *}(0.0142)$ \\
\hline Experience (in years) & $-0.0179^{* * *}(0.0041)$ & $-0.0134^{* * *}(0.0047)$ & $-0.0009(0.0177)$ & $-0.0159^{* * *}(0.0045)$ & $-0.0130^{* *}(0.0051)$ & $-0.0039(0.0179)$ \\
\hline Level 1 (Top Management) & $0.8729^{\star \star \star}(0.1706)$ & $0.7286^{\star \star *}(0.2080)$ & $0.1846(0.4555)$ & $0.9239^{\star * *}(0.1777)$ & $0.7316^{* * *}(0.2174)$ & $0.0915(0.4633)$ \\
\hline Level 2 & $0.3637^{\star * *}(0.0635)$ & $0.2930^{* * *}(0.0704)$ & $0.0866(0.1289)$ & $0.3893^{\star * \star}(0.0674)$ & $0.2993^{\star * *}(0.0744)$ & $0.0425(0.1331)$ \\
\hline Level 3 & -- & -- & -- & -- & -- & --- \\
\hline Level 4 & $-0.3459^{\star \star \star}(0.0438)$ & $-0.3178^{\star \star *}(0.0460)$ & $-0.2441^{\star \star *}(0.0747)$ & $-0.3609^{* \star *}(0.0473)$ & $-0.3172^{\star \star \star}(0.0492)$ & $-0.2033^{\star * *}(0.0779)$ \\
\hline 2008 & $0.0212(0.0493)$ & $0.0360(0.0404)$ & $-0.0157(0.0627)$ & $0.0152(0.0503)$ & $0.0303(0.0414)$ & $-0.0085(0.0662)$ \\
\hline 2009 & $0.0026(0.0487)$ & $0.0011(0.0370)$ & $-0.0458(0.0456)$ & $-0.0001(0.0487)$ & $-0.0012(0.0370)$ & $-0.0413(0.0460)$ \\
\hline 2010 & --- & --- & --- & --- & --- & --- \\
\hline 2011 & $-0.0474(0.0492)$ & $-0.0621(0.0383)$ & $-0.0277(0.0489)$ & $-0.0490(0.0498)$ & $-0.0665^{\star}(0.0387)$ & $-0.0429(0.0518)$ \\
\hline Constant & $6.7124^{* * *}(0.1119)$ & $6.7479^{* * *}(0.1221)$ & $7.8202^{\star * *}(0.4873)$ & $6.6846^{* * *}(0.1367)$ & $6.7294^{* * *}(0.1468)$ & $7.6431^{* * *}(0.5741)$ \\
\hline Observations (persons) & 14,773 & $14,773(7,538)$ & $14,773(7,538)$ & 14,773 & $14,773(7,538)$ & $14,773(7,538)$ \\
\hline $\mathrm{R}^{2}$ (overall) & 0.0317 & 0.0308 & 0.0030 & 0.0328 & 0.0317 & 0.0033 \\
\hline
\end{tabular}

Notes: Robust standard errors in parentheses. All wages are divided by 1,000 
Table 10: Social comparisons on the firm level (absolute differences)

\begin{tabular}{|c|c|c|c|c|c|c|}
\hline & \multicolumn{6}{|c|}{ Dependent variable: job satisfaction } \\
\hline & $\begin{array}{c}\text { (1) } \\
\text { Total OLS }\end{array}$ & $\begin{array}{c}(2) \\
\text { Total RE }\end{array}$ & $\begin{array}{c}\text { (3) } \\
\text { Total FE }\end{array}$ & $\begin{array}{c}(4) \\
\text { Fix/Bonus OLS }\end{array}$ & $\begin{array}{c}\text { (5) } \\
\text { Fix/Bonus RE }\end{array}$ & $\begin{array}{c}\text { (6) } \\
\text { Fix/Bonus FE }\end{array}$ \\
\hline Total Compensation & $0.0039^{* * *}(0.0013)$ & $0.0021(0.0013)$ & $-0.0013(0.0015)$ & & & \\
\hline Total Comp $p^{\text {ref }}$ & $-0.0049^{\star *}(0.0022)$ & $-0.0004(0.0024)$ & $0.0054(0.0038)$ & & & \\
\hline Fixed Salary & & & & $0.0057(0.0035)$ & $0.0057(0.0037)$ & $0.0036(0.0064)$ \\
\hline Fixed Salary ${ }^{\text {ref }}$ & & & & $-0.0030(0.0067)$ & $-0.0008(0.0067)$ & $0.0004(0.0097)$ \\
\hline Bonus & & & & $0.0105^{\star \star}(0.0042)$ & $0.0045(0.0041)$ & $-0.0070(0.0061)$ \\
\hline Bonus $^{\text {ref }}$ & & & & $-0.0146^{* *}(0.0068)$ & $-0.0057(0.0058)$ & $0.0065(0.0068)$ \\
\hline Female (dummy) & $0.1368(0.1250)$ & $0.1376(0.1515)$ & & $0.1434(0.1250)$ & $0.1472(0.1513)$ & \\
\hline In Relationship (dummy) & $-0.0254(0.1287)$ & $-0.1148(0.1362)$ & $-0.3311(0.2345)$ & $-0.0410(0.1276)$ & $-0.1319(0.1350)$ & $-0.3383(0.2316)$ \\
\hline Children in Household (1=yes) & $0.1121(0.0805)$ & $0.1335(0.0994)$ & $0.2272(0.2617)$ & $0.1075(0.0805)$ & $0.1285(0.0996)$ & $0.2142(0.2681)$ \\
\hline Distance to workplace (in km) & $-0.0036^{*}(0.0019)$ & $-0.0024(0.0021)$ & $-0.0018(0.0042)$ & $-0.0036^{*}(0.0019)$ & $-0.0024(0.0022)$ & $-0.0020(0.0042)$ \\
\hline Firm Dummies & yes & yes & yes & yes & yes & yes \\
\hline Tenure (in years) & $-0.0207^{\star *}(0.0081)$ & $-0.0174^{*}(0.0098)$ & $-0.0270(0.0272)$ & $-0.0215^{\star * *}(0.0081)$ & $-0.0185^{*}(0.0098)$ & $-0.0247(0.0281)$ \\
\hline Experience (in years) & $0.0036(0.0092)$ & $-0.0015(0.0111)$ & $0.0530(0.0350)$ & $-0.0001(0.0114)$ & $-0.0042(0.0131)$ & $0.0595^{\star}(0.0344)$ \\
\hline Level 1 (Top Management) & $0.9846^{\star *}(0.4024)$ & $0.6562^{*}(0.3427)$ & & $0.6770(0.7405)$ & $0.4155(0.6993)$ & \\
\hline Level 2 & $0.5376^{\star \star \star}(0.2001)$ & $0.3082(0.2307)$ & $-0.1358(0.3865)$ & $0.4682^{\star *}(0.2370)$ & $0.3627(0.2401)$ & $0.1053(0.3863)$ \\
\hline Level 3 & -- & --- & --- & --- & --- & --- \\
\hline Level 4 & $-0.3931^{* \star *}(0.0943)$ & $-0.3501^{\star \star \star}(0.1063)$ & $-0.4514^{\star *}(0.1893)$ & $-0.3643^{\star * *}(0.1174)$ & $-0.3377^{\star * *}(0.1210)$ & $-0.5095^{\star *}(0.2006)$ \\
\hline 2008 & $0.0856(0.0908)$ & $0.0767(0.0779)$ & $0.1619(0.1346)$ & $0.1044(0.0989)$ & $0.0952(0.0840)$ & $0.2035(0.1444)$ \\
\hline 2009 & $0.0664(0.0905)$ & $0.0507(0.0696)$ & $0.0634(0.0864)$ & $0.0805(0.0923)$ & $0.0582(0.0694)$ & $0.0765(0.0877)$ \\
\hline 2010 & --- & --- & --- & --- & --- & --- \\
\hline 2011 & $0.0841(0.0972)$ & $0.0103(0.0808)$ & $-0.0987(0.1067)$ & $0.1010(0.1067)$ & $0.0349(0.0872)$ & $-0.0469(0.1096)$ \\
\hline Constant & $7.6182^{* * *}(0.2279)$ & $7.3863^{* * *}(0.2540)$ & $6.7934^{* * *}(1.0486)$ & $7.4622^{* * *}(0.4127)$ & $7.2617^{* * *}(0.3992)$ & $6.7170^{\star \star \star *}(1.2882)$ \\
\hline Observations (persons) & 3,790 & $3,790(1,904)$ & $3,790(1,904)$ & 3,790 & $3,790(1,904)$ & $3,790(1,904)$ \\
\hline $\mathrm{R}^{2}$ (overall) & 0.0635 & 0.0604 & 0.0343 & 0.0653 & 0.0636 & 0.0335 \\
\hline
\end{tabular}

Notes: Robust standard errors in parentheses. All wages are divided by 1,000 
Table 11: Social comparisons and loss aversion (firm level, absolute differences)

\begin{tabular}{|c|c|c|c|c|c|c|}
\hline & & & Dependent varia & job satisfaction & & \\
\hline & $\begin{array}{c}(1) \\
\text { Total OLS }\end{array}$ & $\begin{array}{c}(2) \\
\text { Total RE }\end{array}$ & $\begin{array}{c}\text { (3) } \\
\text { Total FE }\end{array}$ & $\begin{array}{c}(4) \\
\text { Fix/Bonus OLS }\end{array}$ & $\begin{array}{c}\text { (5) } \\
\text { Fix/Bonus RE }\end{array}$ & $\begin{array}{c}(6) \\
\text { Fix/Bonus FE }\end{array}$ \\
\hline $\begin{array}{l}\text { Total Compensation } \\
\left(\text { Total Comp - Total Comp }{ }^{\text {ref }}\right) \\
\left(\text { Total Comp - Total Comp }{ }^{\text {ref }}\right)^{\star} \text { Below }\end{array}$ & $\begin{array}{l}-0.0003(0.0018) \\
0.0032(0.0029) \\
0.0037(0.0044)\end{array}$ & $\begin{array}{l}0.0025(0.0019) \\
-0.0017(0.0029) \\
0.0048(0.0043) \\
\end{array}$ & $\begin{array}{c}0.0044(0.0030) \\
-0.0062(0.0042) \\
0.0022(0.0060)\end{array}$ & & & \\
\hline 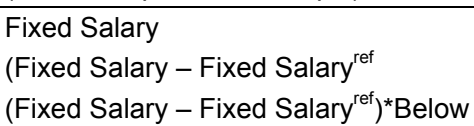 & & & & $\begin{array}{l}0.0028(0.0060) \\
0.0023(0.0079) \\
0.0014(0.0094)\end{array}$ & $\begin{array}{c}0.0050(0.0057) \\
-0.0005(0.0079) \\
0.0027(0.0092)\end{array}$ & $\begin{array}{c}0.0037(0.0082) \\
-0.0044(0.0114) \\
0.0084(0.0127)\end{array}$ \\
\hline $\begin{array}{l}\text { Bonus } \\
\left(\text { Bonus }- \text { Bonus }^{\text {ref }}\right) \\
\left(\text { Bonus }- \text { Bonus }{ }^{\text {ref }}\right)^{*} \text { Below }\end{array}$ & & & & $\begin{array}{c}-0.0037(0.0058) \\
0.0136^{*}(0.0080) \\
0.0033(0.0118)\end{array}$ & $\begin{array}{l}-0.0008(0.0050) \\
0.0047(0.0074) \\
0.0033(0.0106)\end{array}$ & $\begin{array}{l}-0.0009(0.0054) \\
-0.0053(0.0089) \\
-0.0017(0.0133)\end{array}$ \\
\hline Female (dummy) & $0.1404(0.1250)$ & $0.1437(0.1516)$ & & $0.1445(0.1250)$ & $0.1498(0.1514)$ & \\
\hline In Relationship (dummy) & $-0.0293(0.1283)$ & $-0.1179(0.1361)$ & $-0.3318(0.2351)$ & $-0.0421(0.1275)$ & $-0.1326(0.1351)$ & $-0.3353(0.2337)$ \\
\hline Children in Household (1=yes) & $0.1122(0.0805)$ & $0.1329(0.0994)$ & $0.2271(0.2621)$ & $0.1078(0.0805)$ & $0.1294(0.0997)$ & $0.2168(0.2685)$ \\
\hline Distance to workplace (in km) & $-0.0036^{*}(0.0019)$ & $-0.0024(0.0022)$ & $-0.0019(0.0042)$ & $-0.0036^{*}(0.0019)$ & $-0.0024(0.0022)$ & $-0.0021(0.0042)$ \\
\hline Firm Dummies & yes & yes & yes & yes & yes & yes \\
\hline Tenure (in years) & $-0.0211^{* * *}(0.0081)$ & $-0.0179^{*}(0.0098)$ & $-0.0271(0.0271)$ & $-0.0217^{* * *}(0.0082)$ & $-0.0188^{*}(0.0098)$ & $-0.0238(0.0281)$ \\
\hline Experience (in years) & $0.0035(0.0092)$ & $-0.0017(0.0111)$ & $0.0528(0.0351)$ & $0.0001(0.0114)$ & $-0.0038(0.0131)$ & $0.0583^{*}(0.0344)$ \\
\hline Level 2 & $0.5335^{\star * *}(0.2008)$ & $0.3124(0.2315)$ & $-0.1220(0.3938)$ & $0.4754^{\star \star}(0.2370)$ & $0.3709(0.2407)$ & $0.0938(0.3858)$ \\
\hline Level 3 & --- & --- & --- & --- & --- & --- \\
\hline Level 4 & $-0.3833^{\star \star *}(0.0949)$ & $-0.3414^{\star \star *}(0.1065)$ & $-0.4542^{\star \star}(0.1904)$ & $-0.3636^{\star \star *}(0.1173)$ & $-0.3383^{\star * \star}(0.1208)$ & $-0.5116^{\star \star}(0.2003)$ \\
\hline 2008 & $0.0848(0.0908)$ & $0.0763(0.0778)$ & $0.1629(0.1348)$ & $0.1049(0.0989)$ & $0.0961(0.0841)$ & $0.2023(0.1435)$ \\
\hline 2009 & $0.0654(0.0905)$ & $0.0493(0.0696)$ & $0.0632(0.0864)$ & $0.0804(0.0922)$ & $0.0583(0.0696)$ & $0.0772(0.0879)$ \\
\hline 2010 & --- & --- & --- & --- & --- & --- \\
\hline 2011 & $0.0777(0.0975)$ & $0.0030(0.0805)$ & $-0.1018(0.1067)$ & $0.0997(0.1069)$ & $0.0335(0.0877)$ & $-0.0402(0.1098)$ \\
\hline Constant & $7.5763^{* \star *}(0.2347)$ & $7.3379^{* \star *}(0.2571)$ & $5.4246^{* * *}(1.1246)$ & $7.4579^{* * *}(0.4121)$ & $7.2584^{* \star *}(0.3983)$ & $5.4131^{* * *}(1.3239)$ \\
\hline Observations (persons) & 3,790 & $3,790(1,904)$ & $3,790(1,904)$ & 3,790 & $3,790(1,904)$ & $3,790(1,904)$ \\
\hline$R^{2}$ (overall) & 0.0628 & 0.0607 & 0.0018 & 0.0654 & 0.0636 & 0.0015 \\
\hline
\end{tabular}

Notes: Robust standard errors in parentheses. All wages are divided by 1,000 . 
Table 12: Social comparisons on the market level - male vs. female

\begin{tabular}{|c|c|c|c|c|}
\hline & \multicolumn{4}{|c|}{ Dependent variable: job satisfaction; fixed-effects estimations } \\
\hline & $\begin{array}{c}(1) \\
\text { Male }\end{array}$ & $\begin{array}{c}(2) \\
\text { Female }\end{array}$ & $\begin{array}{c}(3) \\
\text { Male }\end{array}$ & $\begin{array}{c}(4) \\
\text { Female }\end{array}$ \\
\hline $\begin{array}{l}\text { Total Compensation } \\
\text { Total Comp } \\
\text { ref }\end{array}$ & $\begin{array}{c}0.0012(0.0010) \\
-0.0123^{\star \star}(0.0049)\end{array}$ & $\begin{array}{l}0.0126^{* *}(0.0061) \\
-0.0004(0.0140)\end{array}$ & & \\
\hline $\begin{array}{l}\text { Fixed Salary } \\
\text { Fixed Salary }\end{array}$ & & & $\begin{array}{c}0.0051(0.0036) \\
-0.0268^{\star \star}(0.0116)\end{array}$ & $\begin{array}{l}0.0215(0.0134) \\
-0.0037(0.0447)\end{array}$ \\
\hline $\begin{array}{l}\text { Bonus } \\
\text { Bonus }^{\text {ref }}\end{array}$ & & & $\begin{array}{l}0.0014(0.0022) \\
-0.0068(0.0087)\end{array}$ & $\begin{array}{c}0.0207^{\star \star}(0.0097) \\
0.0041(0.0337)\end{array}$ \\
\hline $\begin{array}{l}\text { Observations (persons) } \\
R^{2} \text { overall }\end{array}$ & $\begin{array}{c}13,289(6,718) \\
0.0022\end{array}$ & $\begin{array}{c}1,484(832) \\
0.0025\end{array}$ & $\begin{array}{c}13,289(6,718) \\
0.0042\end{array}$ & $\begin{array}{c}1,484(832) \\
0.0018\end{array}$ \\
\hline
\end{tabular}

Notes: Robust standard errors in parentheses. All wages are divided by 1,000. The models are in all other respects identical to models (3) and (6) of Table 6.

Table 13: Social comparisons on the market level - firm size classes

\begin{tabular}{|c|c|c|c|c|c|c|}
\hline & \multicolumn{6}{|c|}{ Dependent variable: job satisfaction; fixed-effects estimations } \\
\hline & $\begin{array}{c}(1) \\
\leq 1,000 \mathrm{emp} .\end{array}$ & $\begin{array}{c}(2) \\
1-10,000 \mathrm{emp} .\end{array}$ & $\begin{array}{c}(3) \\
>10,000 \mathrm{emp}\end{array}$ & $\begin{array}{c}(4) \\
\leq 1,000 \mathrm{emp}\end{array}$ & $\begin{array}{c}(5) \\
1-10,000 \text { emp. }\end{array}$ & $\begin{array}{c}(6) \\
>10,000 \text { emp. }\end{array}$ \\
\hline Total Comp & $0.0047(0.0033)$ & $0.0036(0.0028)$ & $0.0001(0.0009)$ & & & \\
\hline Total Comp ${ }^{\text {ref }}$ & $-0.0358^{\star \star *}(0.0101)$ & $-0.0173^{*}(0.0102)$ & $-0.0144^{*}(0.008)$ & & & \\
\hline Fixed Salary & & & & $0.0047(0.0089)$ & $0.0094^{*}(0.0057)$ & $0.0054(0.0048)$ \\
\hline Fixed Salary ${ }^{\text {ref }}$ & & & & $-0.0305(0.0382)$ & $-0.0144(0.0192)$ & $0.0112(0.0213)$ \\
\hline Bonus & & & & $0.0024(0.0043)$ & $0.0059(0.0040)$ & $0.0008(0.0032)$ \\
\hline Bonus $^{\text {ref }}$ & & & & $-0.0744(0.0559)$ & $-0.0312(0.0208)$ & $-0.0496^{* * *}(0.0190)$ \\
\hline Obs. (persons) & $2,771(1,622)$ & $5,147(2,890)$ & $6,915(3,633)$ & $2,771(1,622)$ & $5,147(2,890)$ & $6,915(3,633)$ \\
\hline $\mathrm{R}^{2}$ (overall) & 0.0049 & 0.0047 & 0.0031 & 0.0048 & 0.0102 & 0.0056 \\
\hline
\end{tabular}

Notes: Robust standard errors in parentheses. All wages are divided by 1,000. The models are in all other respects identical to models (3) and (6) of Table 6. 


\section{Appendix}

Table A1: Variable definitions and operationalizations

\begin{tabular}{|c|c|}
\hline$\underline{\text { Variable }}$ & Description \\
\hline Job satisfaction & $\begin{array}{l}\text { Overall satisfaction with the job, measured on a 11-digit } \\
\text { scale from } 0 \text { (totally unhappy) to } 10 \text { (totally happy) }\end{array}$ \\
\hline Total Compensation & $\begin{array}{l}\text { Gross annual total monetary compensation in 1,000 Euro. } \\
\text { Computed as the sum of fixed salaries, bonus payments } \\
\text { and other income components (such as exercises stock } \\
\text { options, inventors' gratuities or jubilee payments) }\end{array}$ \\
\hline Fixed Salaries & $\begin{array}{l}\text { Gross annual fixed salaries in 1,000 Euro, guaranteed by } \\
\text { the work contract }\end{array}$ \\
\hline Bonus Payments & Gross annual bonus payments in 1,000 Euro \\
\hline $\begin{array}{l}\text { Reference Total } \\
\text { Compensation (Fixed } \\
\text { Salaries, Bonus Payments) }\end{array}$ & $\begin{array}{l}\text { Average gross annual total monetary compensation (fixed } \\
\text { salaries, bonus payments) in 1,000 Euro of a reference } \\
\text { group. Regarding social comparisons on the market level: } \\
\text { managers with the same work experience in the same firm } \\
\text { size on the same hierarchical level in the same year. } \\
\text { Regarding social comparisons on the firm level: managers } \\
\text { with the same work experience on the same hierarchical } \\
\text { level in the same firm in the same year }\end{array}$ \\
\hline Female & Dummy for females (1=yes) \\
\hline In Relationship & Dummy for being in a relationship (1=yes) \\
\hline Children in household & Dummy for minor child(ren) in household \\
\hline Distance to workplace & One-way distance to the workplace in kilometers \\
\hline Tenure & Tenure with the firm in years \\
\hline Experience & Work experience, measured by the years since graduation \\
\hline Firm size & $\begin{array}{l}\text { Dummies for the size of the actual firm in which the } \\
\text { manager is occupied. As a proxy, the number of } \\
\text { employees of the firm is used. There are eight different } \\
\text { categories: (1) Up to } 100 \text { employees, (2) } 101-300 \\
\text { employees, (3) } 301-1,000 \text { employees, (4) } 1,001-2,000 \\
\text { employees, (5) } 2,001-5,000 \text { employees, (6) } 5,001-10,000 \\
\text { employees, (7) } 10,001-30,000 \text { employee and (8) at least } \\
30,001 \text { employees }\end{array}$ \\
\hline Hierarchical Level & $\begin{array}{l}\text { Dummies for the hierarchical level on which the managers } \\
\text { works. Within the questionnaire, respondents are asked to } \\
\text { allocate them to one of four management levels, whereas } \\
\text { level } 1 \text { represents the top-management level }\end{array}$ \\
\hline Year & Dummies for the observation year \\
\hline
\end{tabular}

